\title{
House of Commons
}

\section{International Development}

Committee

\section{AFGHANISTAN: \\ THE TRANSITION FROM \\ HUMANITARIAN RELIEF \\ TO RECONSTRUCTION \\ AND DEVELOPMENT \\ ASSISTANCE}

First Report of Session 2002-03 


\section{INTERNATIONAL DEVELOPMENT SELECT COMMITTEE PUBLICATIONS IN THE CURRENT PARLIAMENT}

Session 2001-2002

\section{Reports:}

FIRST REPORT

HC 300-I and II

The Humanitarian Crisis in Afghanistan and the Surrounding Region

FIRST SPECIAL REPORT

HC 633

Government Response to the Committee's First Report of Session 2001-02

SECOND REPORT

The Effectiveness of the Reforms of European Development Assistance

HC 417-I and II

SECOND SPECIAL REPORT

HC 1027

Government Response to the Committee's Second Report of Session 2001-02

THIRD REPORT

HC 519-I and II

Global Climate Change and Sustainable Development

FOURTH SPECIAL REPORT

HC 1270

Government Response to the Committee's Third Report of Session 2001-02

FOURTH REPORT

$\mathrm{HC} 718$

Strategic Export Controls: Annual Report for 2000, Licensing Policy and Prior Parliamentary Scrutiny

FIFTH REPORT

HC 785-I and II

Financing for Development: Finding the Money to Eliminate World Poverty

THIRD SPECIAL REPORT

HC 1269

Government Response to the Committee's Fifth Report of Session 2001-02

SIXTH REPORT

HC 964

Department for International Development: Departmental Report 2002

Minutes of Evidence:

Afghanistan: Further Developments, 26 February 2002

HC 653

Africa, NEPAD and the G8 Africa Action Plan, 16 July 2002

HC 1107

The Autumn Meetings of the IMF and the World Bank, 5 November 2002

HC 1297-i /

HC 256

Minutes of Proceedings

HC 1326 


\title{
House of Commons
}

\section{International Development Committee}

\section{AFGHANISTAN: \\ THE TRANSITION FROM \\ HUMANITARIAN RELIEF TO \\ RECONSTRUCTION \\ AND DEVELOPMENT ASSISTANCE}

First Report of Session 2002-03

\begin{abstract}
Report, together with Proceedings of the Committee, Minutes of Evidence and Appendices
\end{abstract}

Ordered by The House of Commons to be printed 14 January 2003

$\mathrm{HC} 84$

[Incorporating 1260-i, Session 2001-02]

Published on 23 January 2003 by authority of the House of Commons London: The Stationery Office Limited 


\section{INTERNATIONAL DEVELOPMENT COMMITTEE}

The International Development Committee is appointed by the House of Commons to examine the expenditure, administration and policy of the Department for International Development and its associated public bodies.

\section{Current Membership}

Tony Baldry MP (Conservative, Banbury) (Chairman)

John Barrett MP (Liberal Democrat, Edinburgh West)

Mr John Battle MP (Labour, Leeds West)

Hugh Bayley MP (Labour, City of York)

Alistair Burt MP (Conservative, North East Bedfordshire)

Ann Clwyd MP (Labour, Cynon Valley)

Mr Tony Colman MP (Labour, Putney)

Mr Piara S Khabra MP (Labour, Ealing Southall)

Chris McCafferty MP (Labour, Calder Valley)

Mr Robert Walter MP (Conservative, North Dorset)

Tony Worthington MP (Labour, Clydebank and Milngavie)

Mr Andrew Robathan MP (Conservative, Blaby) was also a member of the Committee during this inquiry

\section{Powers}

The Committee is one of the departmental select committees, the powers of which are set out in the House of Commons Standing Orders, principally SO No. 152. These are available on the Internet via www.parliament.uk.

\section{Publications}

The Reports and evidence of the Committee are published by The Stationery Office by Order of the House. All publications of the Committee (including press notices) are on the Internet at http://www.parliament.uk./parliamentary committees/international

development.cfm

\section{Contacts}

All correspondence should be addressed to The Clerk of the International Development Committee, Committee Office, 7 Millbank, London SW1P 3JA. The telephone number for general enquiries is: 0207219 1223; the Committee's e-mail address is: indcom@parliament.uk.

\section{Footnotes}

In the footnotes of this Report, references to oral evidence are indicated by ' $Q$ ' followed by the question number. References to written evidence are indicated by the page number as in ' $\mathrm{Ev} 12$ '. 


\section{TABLE OF CONTENTS}

REPORT

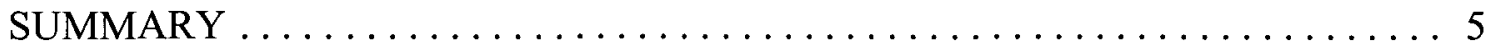

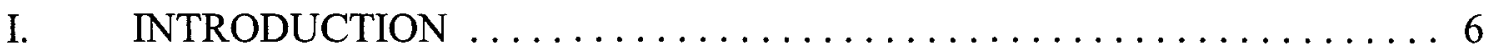

II. RESOURCES $\ldots \ldots \ldots \ldots \ldots \ldots \ldots \ldots \ldots \ldots \ldots \ldots \ldots$

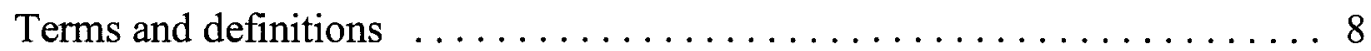

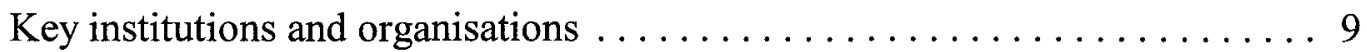

The breakdown of the Tokyo money by donor $\ldots \ldots \ldots \ldots \ldots \ldots$

Levels of funding . ........................... 11

The balance of spending: from humanitarian relief to reconstruction

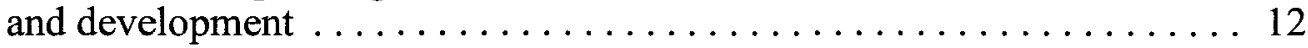

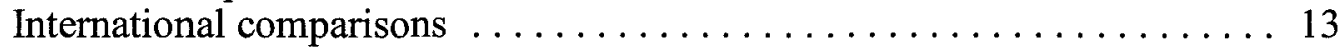

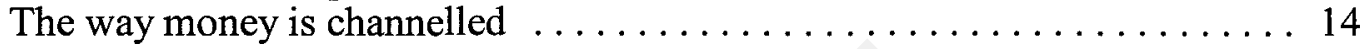

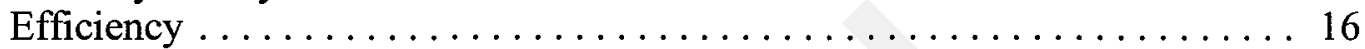

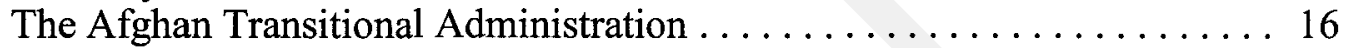

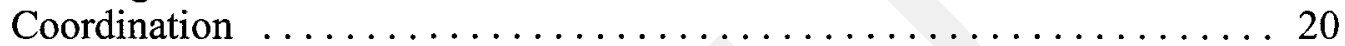

The Role of NGOs . . . . . . . . . . . . . . . . . . . . . 21

Transaction costs ............................. 22

The Afghanistan Reconstruction Trust Fund-A way forward? . . . . . . 24

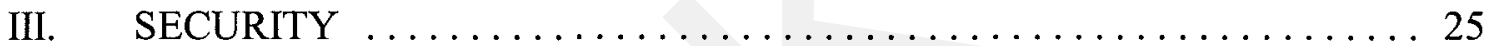

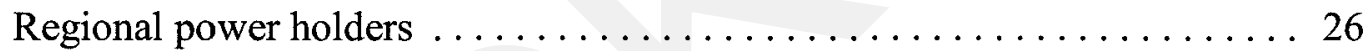

The International Security Assistance Force $\ldots \ldots \ldots \ldots \ldots \ldots \ldots 27$

Joint Regional Teams . . . . . . . . . . . . . . . . . . . . 28

Long-term security for Afghanistan . . . . . . . . . . . . . . . . 29

A National Army and Police Force . . . . . . . . . . . . . . . . . . . 29

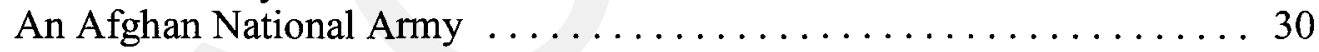

A Police Force . ............................. 30

Disarmament, demobilisation and reintegration $\ldots \ldots \ldots \ldots \ldots \ldots \ldots \ldots$

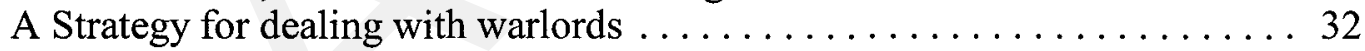

The Judiciary and criminal justice system $\ldots \ldots \ldots \ldots \ldots \ldots \ldots \ldots \ldots \ldots$

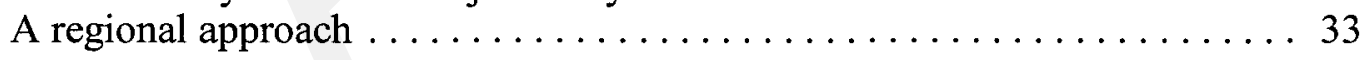

IV. CONTINUING HUMANITARIAN NEEDS-FOOD AID AND

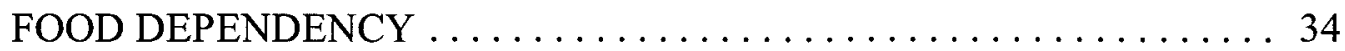

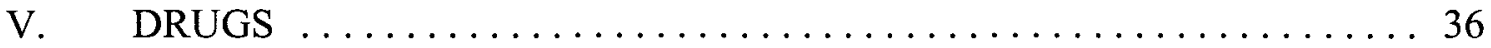

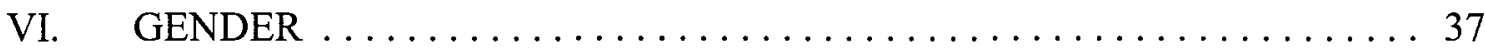

VII. REFUGEES AND INTERNALLY DISPLACED PEOPLE . . . . . . . . 39

VIII. HUMAN RIGHTS $\ldots \ldots \ldots \ldots \ldots \ldots \ldots \ldots \ldots \ldots \ldots \ldots \ldots \ldots \ldots$

IX. PRIVATE SECTOR DEVELOPMENT $\ldots \ldots \ldots \ldots \ldots \ldots \ldots \ldots$

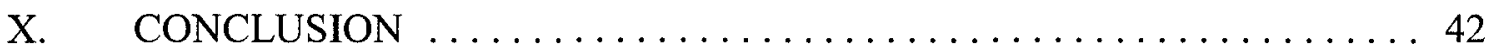

LIST OF MAIN CONCLUSIONS AND RECOMMENDATIONS . . . . . . . . . 44

PROCEEDINGS OF THE COMMITTEE RELATING TO THE REPORT . . . . . 49

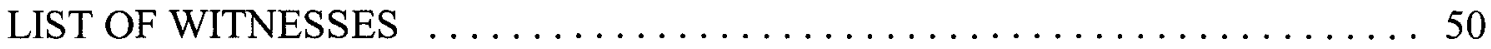

LIST OF MEMORANDA INCLUDED IN THE MINUTES OF EVIDENCE . . . . 51

LIST OF APPENDICES TO THE MINUTES OF EVIDENCE $\ldots \ldots \ldots \ldots \ldots \ldots . \ldots 1$

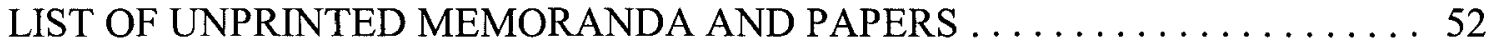




\section{AFGHANISTAN}

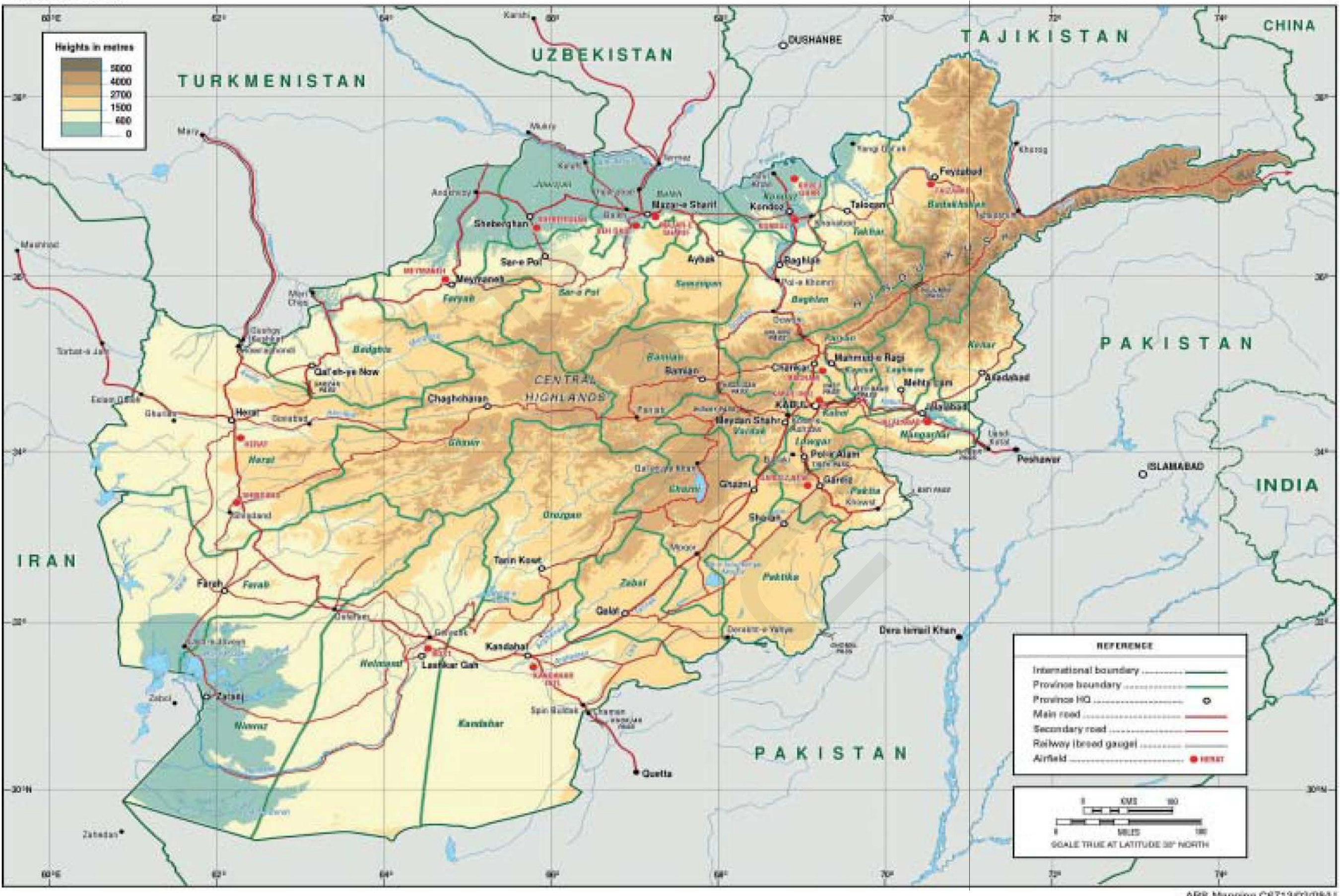

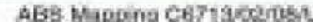




\title{
FIRST REPORT
}

The International Development Committee has agreed to the following Report:

\section{AFGHANISTAN: THE TRANSITION FROM HUMANITARIAN RELIEF TO RECONSTRUCTION AND DEVELOPMENT ASSISTANCE}

\begin{abstract}
SUMMARY
Our previous report on Afghanistan dealt with a drought and conflict-related humanitarian crisis. In this report we investigate what progress has been made from dependence on humanitarian aid, to the reconstruction and development of a wrecked country with no institutions that work, no legitimate economy, no order or security and a serious lack of capacity within government.
\end{abstract}

We found that the funds available are simply not enough. International donors pledged around US\$5 billion over a five year period for Afghanistan's reconstruction at the Tokyo Conference. This was less than half what preliminary estimates suggested would be needed. It should have allowed the reconstruction process to begin in earnest. Unfortunately, the continuing humanitarian crisis has meant that most of these resources have been used for humanitarian relief and some of the funds committed have been in the form of food aid in kind. A further round of pledging will be necessary with commitments designed to flow at a rate determined by the absorptive capacity of the Afghan Transitional Administration (ATA) and of the UN system.

Outside Kabul the Afghan Transitional Administration has little or no authority. The UN and NGO system is therefore the provider of services for the Afghan people and has come to operate as a parallel structure to the ATA. This situation has arisen out of necessity. The ATA lacks the capacity to absorb funds or spend them effectively. It is unable to deliver the services which people expect their government to deliver. A massive programme of institution building and capacity development is needed if an effective state is to emerge. There is a tension between the need to deliver services quickly, and the need to operate through the ATA and thereby enhance its authority. Elections are only eighteen months away. Donors need to have a clearer strategy for handing over responsibilities to the Afghan authorities. We have made suggestions about possible changes to the way resources are channelled which could assist in meeting these objectives.

The lack of security remains the most pressing problem. It presents a major obstacle to both humanitarian relief and reconstruction. The ATA's lack of control outside Kabul has left "warlords" as the de facto rulers in many provinces. Achieving a normal security climate in Afghanistan will require a reduction in the power of the warlords and an increase in the authority of central government. The absence of a working criminal justice system is barrier to stability; establishing a legal framework and the mechanisms to implement it will be the primary method of controlling warlords, preventing human rights abuses and delivering nationwide security and stability.

The international community has lacked the will to create security on the ground. It was an error not to have an ISAF presence in every city; the best that can be hoped for now is an expansion on the "ISAF effect". The newly created Joint Regional Teams, together with disarmament, demobilisation and reintegration programmes for the armed militias will help. But security is best underpinned by economic development. A comprehensive programme of disarmament can only be successful in conjunction with provision of alternative and legitimate livelihoods for those who have survived either by soldiering or by poppy cultivation. 


\section{INTRODUCTION}

1. In December 2001, the Committee published a Report on the humanitarian crisis in Afghanistan and the surrounding region. ${ }^{.}$That Report examined the impact of September 11 , and the conflict which followed, on what was already a drought-related food crisis in Afghanistan. At the time, the Committee stated its intention to return to the subject and this report is the result, conceived as a snapshot of where Afghanistan lies on the path from humanitarian relief to reconstruction and development.

2. Our inquiry has focussed on the progress made towards reconstruction and examined the shift from immediate food assistance to strategies for long-term sustainable development. While the situation in Afghanistan is not as bad as it was a year ago, the World Food Programme (WFP) has estimated that six million people remain vulnerable. ${ }^{2}$ Progress has been made since we reported on what was then a food crisis compounded by conflict but, in terms of reconstruction, work has only just begun. Those concerned have been anxious to emphasise the need to ensure that the international community does not "walk away from Afghanistan"."

3. As part of the inquiry, three Members of the Committee visited Afghanistan in October 2002. Meetings were held in Kabul with President Karzai, Ministers in the Afghan Transitional Administration, United Nations Agencies and other major players working in the field. The Committee's programme was heavily influenced by security conditions. Nevertheless, we managed to travel beyond Kabul to the Shomali Valley, and saw camps for refugees and internally displaced people as well as visiting a girls' school and a family planning clinic. The visit provided us with the opportunity to see at first hand the progress made and to talk with those directly involved in the rebuilding of Afghanistan. We also took oral evidence in the UK from a range of witnesses including the Secretary of State and Ministers of Finance and Planning from the Afghan Transitional Administration.

4. We were struck by the devastation and poverty of the country and saw little evidence that large scale reconstruction had taken place. It was also apparent that the humanitarian crisis was far from over. Many Afghans still have little or no easy access to electricity or even water. ${ }^{4}$ Many people are in vulnerable positions which will be made worse by the winter and the unexpectedly high rate of return of refugees has further compounded the humanitarian situation. ${ }^{5}$ Although the WFP expects to be able to meet the requirements of those facing food insecurity in areas that are inaccessible during the winter, it is anticipating breaks in its food pipeline over the coming months. ${ }^{6}$ Because of the severity of the humanitarian crisis of 2001 and its continuation, the majority of the funding provided by the international community has been absorbed by the humanitarian relief effort which has left minimal funds for reconstruction work. ${ }^{7}$ But the humanitarian work has been essential. It has resulted in lives being saved and what little reconstruction work has been done has made a significant impact. As Chris Austin, Head of DFID's Western Asia Department said in evidence:"'The needs are massive. Whatever you do is going to be of benefit in its own right".

5. In June 2002 the Afghan Interim Authority (AIA) gave way to the Afghan Transitional Administration. Hamid Karzai was chosen as the interim head of state at the Loya Jirga, a traditional assembly of representatives of different groups, and he went on to nominate

\footnotetext{
${ }_{2}^{1}$ First Report, 2001-02, The Humanitarian Crisis in Afghanistan and the Surrounding Region (HC 300-I)

2 Q182

${ }^{3} \mathrm{Q} 156$

${ }_{5}^{4} \mathrm{Q} 182$

${ }^{5}$ Ev 80

${ }_{7}^{6}$ Afghanistan: Monthly Review, British Agencies Afghanistan Group, October 2002

${ }^{7}$ Ev 80

${ }^{8} \mathrm{Q} 35$
} 
the members of his administration. The Transitional Administration is due to serve until 2004 and is tasked with the drafting of a constitution and preparation for elections to be held before the end of its term. Shortly after the Tokyo Conference, at which money was pledged to assist in Afghanistan's reconstruction, the United Nations (UN) produced its Immediate and Transitional Assistance Programme for the Afghan People 2002 (ITAP). ${ }^{9}$ The ITAP sought to build a coherent vision for assistance and was developed in consultation with a number of bodies including international and Afghan NonGovernmental Organisations (NGOs).

6. In the Afghan context of numerous donors, NGOs and UN agencies, all with their own objectives and strategies, it is necessary to identify the key development priorities. In April 2002 the Afghan Interim Authority set out its priorities in its National Development Framework and Budget (NDF), a working document which has since been taken over and revised by the Transitional Administration. The NDF sets out its objectives of developing public administration capacity for good governance, reconstruction of infrastructure and services, extending access to basic service such as health and education, accelerating economic growth, improving the economy's competitiveness and reducing its vulnerability to economic shocks. ${ }^{10}$ From the very beginning, Lakhdar Brahimi, the UN Special Adviser to the Special Representative of the UN Secretary General, stressed that the UN community should leave a "light footprint" and that Afghans should take the lead in the development of Afghanistan. The question of whose agenda, that of the Afghan people or the international community, is being played out in Afghanistan has been an important consideration in this inquiry.

7. This Report does not attempt to provide a comprehensive analysis of Afghanistan's development needs. Rather, we have focussed on what for us were the two glaringly obvious priorities: resources and security. We begin, therefore, by examining the available resources, whether they are adequate, how they have been disbursed and the various way in which funding can be channelled. The second section looks at the security situation and its impact on stability and the prospects for development. The Report then moves on briefly to discuss food aid and dependency, the problem of opium production and the issues of gender, refugees, human rights and private sector development.

8. We are grateful to Elizabeth Winter, our specialist adviser on the inquiry, and all the people and organisations who gave evidence, as well as those who assisted us during our visit to Afghanistan. We would like to thank the following people who gave oral evidence: the Rt Hon Clare Short, Secretary of State for International Development; Dr Abdullah Abdullah, Minister for Foreign Affairs, and Mr Hanif Atmar, Minister for Rural Development and Reconstruction, Transitional Islamic State of Afghanistan; Mr Chris Austin, Head, Western Asia Department, Department for International Development; $\mathrm{Mr}$ Tom Phillips, UK Special Representative for Afghanistan, and Ms Jan Thompson, Head, Afghanistan Unit, Foreign and Commonwealth Office; Mr Shirazuddin Siddiqi, Director, Afghan Education, and Mr Stephen King, Director, BBC World Service Trust; Mukesh Kapila, CBE, United Nations Assistance Mission in Afghanistan (UNAMA); Mr Raja Jarrah, Programme Director, CARE International UK; Mr Sakandar Ali, Country Representative for Afghanistan, Islamic Relief; Ms Judith Randel and Dr Tasneem Mowjee, Development Initiatives; Mr Roger Riddell, International Director, Christian Aid; Mr Peter Marsden, Information Coordinator, and Elizabeth Winter, Special Adviser, British Agencies Afghanistan Group.

\footnotetext{
${ }^{9}$ United Nations, January 2002

${ }^{10}$ It also identifies areas for priority donor engagement which includes the following: National Solidarity Program, Emergency Public Works Programme, Education Infrastructure Project, Urban Infrastructure Project, Water Resource Investment project, National Governance Infrastructure Projects and Transport Project (major roads and airports). Plan and Budget for 1381-82 National Development Programme, Ministries of Planning Reconstruction and Finance, Transitional Government of Afghanistan, Kabul, October 102002
} 


\section{RESOURCES}

9. Prior to the International Conference on Reconstruction Assistance to Afghanistan held in Tokyo in January 2002, a preliminary needs assessment carried out by the World Bank, UNDP and the Asian Development Bank estimated that, as a base case, Afghanistan would need $\$ 14.6$ billion over the next ten years. ${ }^{11}$ At the Tokyo conference international donors pledged approximately US $\$ 4.8$ billion of assistance to Afghanistan. ${ }^{12}$ It had been agreed that commitments made at Tokyo would cover a five year period but in practice most pledges only looked at a two year horizon and included both grants and loans. ${ }^{13}$ Of the Tokyo money, $\$ 1.9$ billion was pledged to be spent in 2002 . Development Initiatives, an aid consultancy specialising in aid policy and monitoring donor behaviour and performance, reported that $\$ 1.8$ billion has been committed to specific agencies, funds or projects, and that by October $2002 \$ 1.4$ billion of that amount had been disbursed. ${ }^{14}$ Some donors have made pledges since the Tokyo conference which has brought the overall sum up to approximately $\$ 5.8$ billion. $^{15}$

10. The Tokyo conference confirmed that existing multilateral and bilateral mechanisms would be the primary vehicle for major donors plus the creation of a single trust fund. Participants also advocated the formation of a common data system for monitoring aid flows. ${ }^{16}$ Despite the fact that the conference was intended to raise money for reconstruction, most estimates indicate that around two thirds of the money spent so far has been spent on humanitarian relief and some of the pledges made at Tokyo have consisted of food aid..$^{17}$ Development Initiatives estimate that out of the USA's $\$ 500$ million pledge, $\$ 200$ million worth has been a donation in kind in the form of "food commodities". ${ }^{18}$ In Afghanistan we heard complaints that some countries' contributions have partly consisted of financial contributions made to the International Security Assistance Force (ISAF) and, in certain cases, even money spent on refugees within their own national borders. Although the UK's contribution does not include its ISAF contribution, donations to UNHCR and the International Organisation for Migration (IOM) for refugee programmes in Afghanistan's neighbours were counted as part of the pledge. ${ }^{19}$ Some of the Tokyo pledges were partly in the form of concessional loans which the Transitional Administration has been reluctant to use. However, President Karzai has since expressed a willingness to use loans within a managed strategy. ${ }^{20}$

\section{Terms and definitions}

11. At Tokyo, governments "pledged" money to Afghanistan. These pledges are statements of a serious intention to supply funding. They are followed by "commitments" when funds have been committed to a specific organisation or sector. Funds are "disbursed" once they have been transferred to the recipient organisation or are available to be drawn down. ${ }^{21}$ Although disbursement means that money has been transferred to the

\footnotetext{
11 Afghanistan: Preliminary Needs Assessment for Recovery and Reconstruction, World Bank, UN Development Programme and Asian Development Bank, January 2002

${ }^{12}$ Ev 68

${ }_{13}^{13} \mathrm{Q} 33$

14 Ev 68

${ }^{15} \mathrm{Q} 91$

${ }^{16}$ Background paper: Funding for Afghanistan-a quick guide to institutions and funds, Afghan Aid Flow Information Bulletin, 9 October 2002 submitted by Development Initiatives. Not printed. The Donor Assistance Database is operational and is managed my the Afghanistan Assistance Coordination Authority

${ }_{18}^{17} \mathrm{Q} 164$

18 Ibid.

${ }_{19}^{19} \mathrm{Q} 40$

${ }^{20} \mathrm{Q} 38$

21 Ev 68
} 
organisation or agency implementing projects, it does not mean that the money has actually been spent. ${ }^{22}$ The following table details the level of disbursement of pledge in 2002:

Figure 1: Assistance to Afghanistan in 2002 from all donors in \$ millions

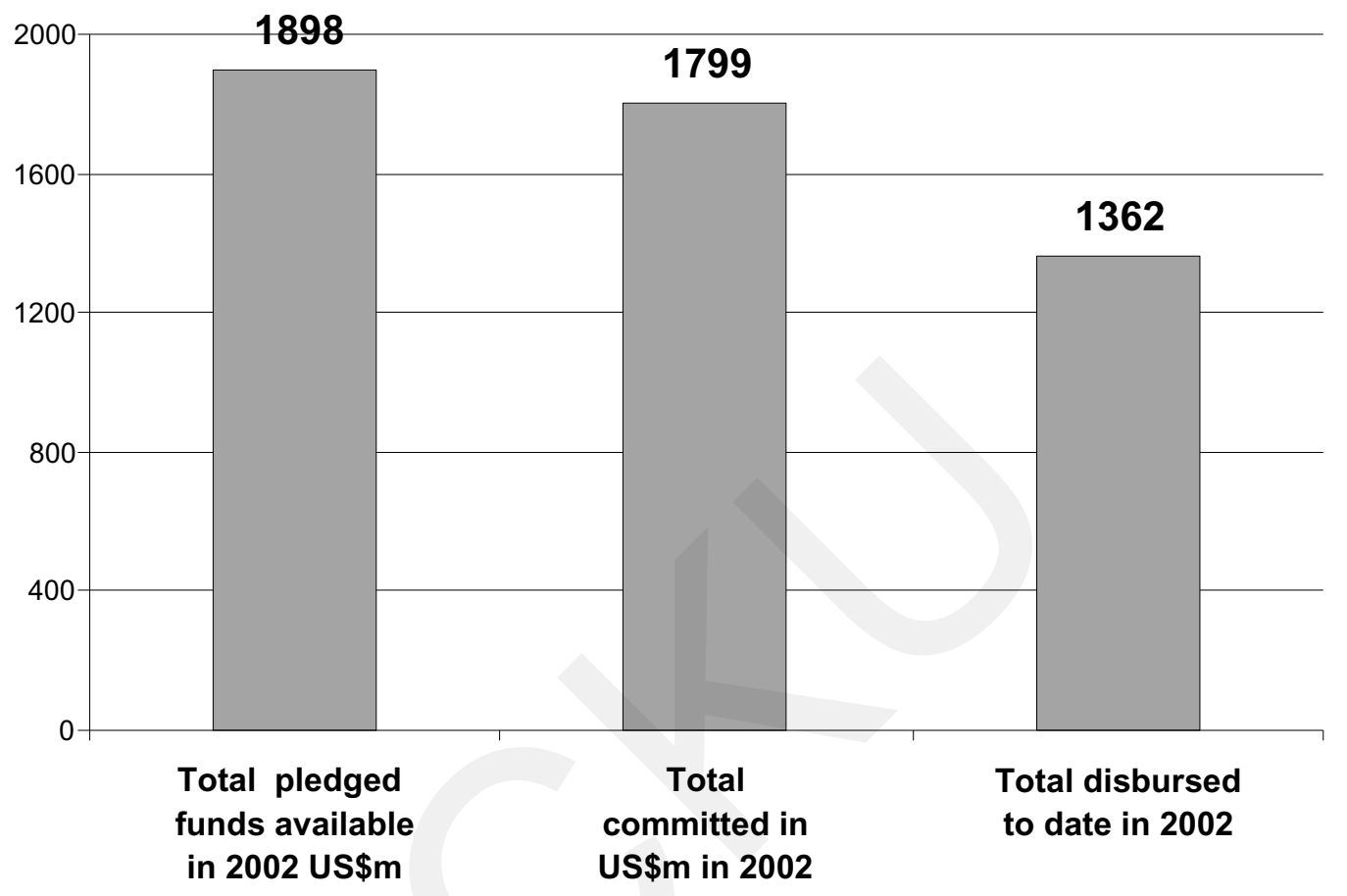

Data source: Development Initiatives as at 19/10/02

\section{Key institutions and organisations}

12. As well as the Afghan Transitional Administration and its Ministries, there are a number of other relevant institutions. The Afghanistan Assistance and Coordination Authority (AACA) is a Transitional Administration agency working to promote an Afghanled vision for reconstruction and development and has played an important role in the production of the National Development Framework. It is also involved in monitoring and tracking aid to Afghanistan using its Donor Assistance Database which is now operational and in use. ${ }^{23}$ The Afghanistan Reconstruction Trust Fund replaced the Afghan Interim Authority Fund in May 2002. As recommended at Tokyo, this single trust fund was established to coordinate donor support within the framework of a unified budget, to fund the Transitional Administration's recurrent budget as well as priority sectoral investment and programme costs and capacity-building projects. ${ }^{24}$

${ }^{22}$ Q161

${ }^{23}$ Background paper: Funding for Afghanistan-a quick guide to institutions and funds, Afghan Aid Flow Information

Bulletin, 9 October 2002 submitted by Development Initiatives. Not printed

${ }^{24}$ Ibid. 


\section{The breakdown of the Tokyo money by donor}

13. Thirty five donors made pledges at Tokyo and the Russian Federation, Lithuania, Singapore, Thailand, New Zealand and Bahrain have made commitments since. The ten largest pledges came from, in descending order: the World Bank, Iran, Asian Development Bank, Japan, United Kingdom, USA, Germany, Saudi Arabia, EC, India, China, Denmark and Pakistan. ${ }^{25}$ Some of these pledges, notably from the USA and India, consisted largely of food aid in kind. The following table shows levels of pledges, commitments and disbursements from the USA, Japan and other Organisation for Economic Co-operation and Development (OECD) Development Assistance Committee (DAC) donors, from EU member states, from non-DAC donors and from Development Banks:

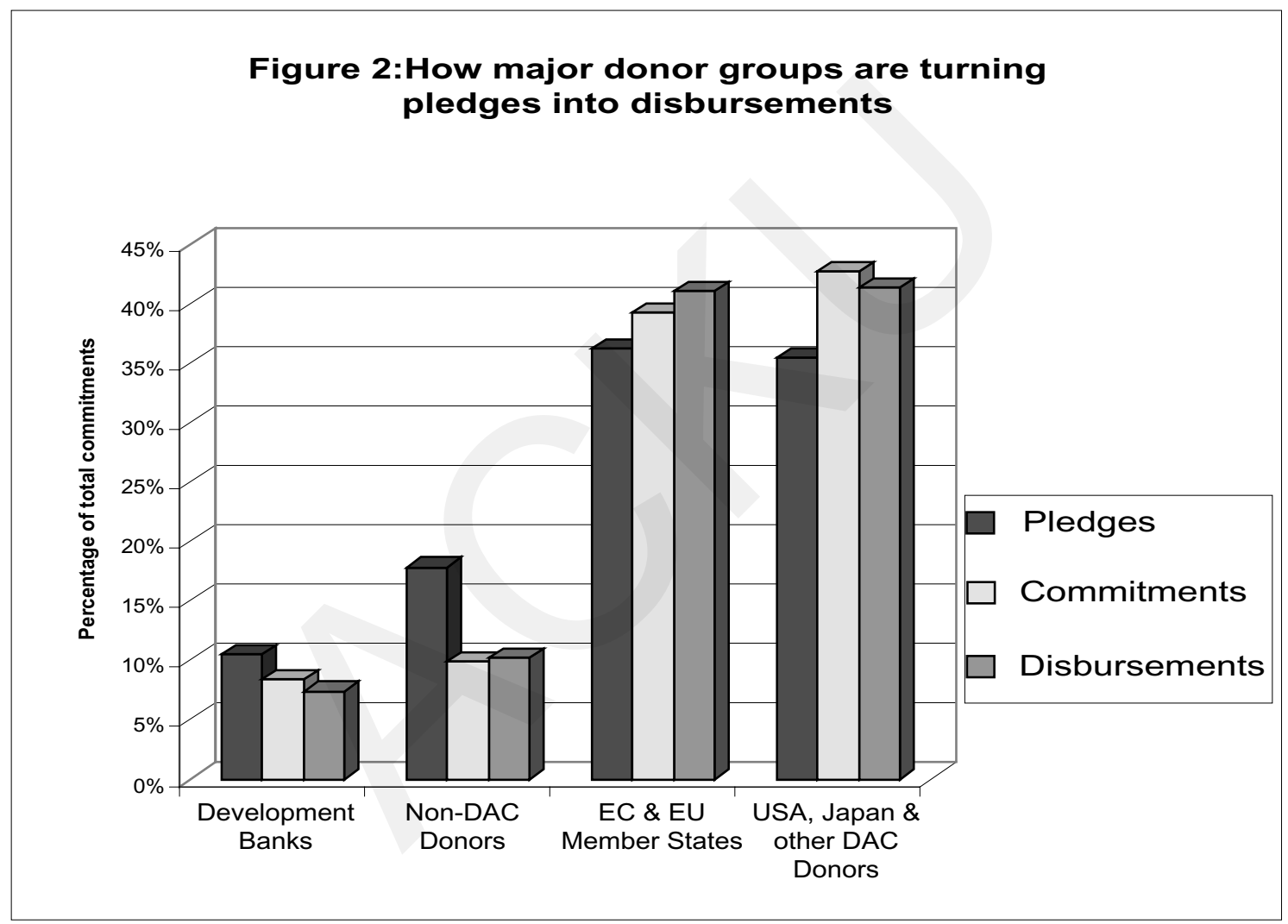

Data source: Development Initiatives as at 19/10/02 
The USA is providing about 30 per cent of total reported commitments. Within the European Union, the UK, Germany and the Netherlands are the three largest providers. ${ }^{26}$ Outside the DAC, the three largest donors were India, Iran and China with Saudi Arabia, Lithuania, Korea, the Russian Federation, Kuwait, Singapore, Turkey, Venezuela and Thailand also making pledges. ${ }^{27}$ As we heard in evidence, the Tokyo money was a very mixed bag with heavy involvement from regional donors; non-DAC members' pledges made up about one third of the total. ${ }^{28}$ We welcome the involvement of regional donors in making pledges to Afghanistan. For too long it has been the same set of countries which put their hands in their pockets when it comes to giving development aid. We urge the UK government to seek to encourage other developed countries to play their full part in the international development system.

\section{Levels of funding}

14. One year on from Tokyo it is clear that the sums pledged are not going to be enough. Almost all of the evidence received from those with experience of what is happening in both urban and rural areas emphasised the need for more money. Those of us who visited Afghanistan returned aware of the enormous amount of work still to be done. Ministers from the Afghan Transitional Administration stated: "We definitely think the pledges made are not going to be sufficient... the World Bank estimate between $\$ 10$ and $\$ 20$ billion...". 29 At a recent meeting of the Afghan Support Group in Oslo, twenty countries pledged a further US $\$ 1.2$ billion and this figure is expected to rise to a total of $\$ 1.7$ billion to be spent in $2003 .^{30}$

15. A possible reason for the apparent underestimation of how much money would be needed for Afghanistan's reconstruction is that the pledges were made on the basis of imperfect information and without a proper needs analysis. ${ }^{31}$ DFID's Chris Austin emphasised that the preliminary needs assessment was something of a back of an envelope calculation saying that: "Tokyo was a fairly rough and ready estimate based on comparisons of how much it cost to rebuild Bosnia and other post-conflict countries but it was not based on thorough analysis of the situation in Afghanistan". ${ }^{32}$ But even the preliminary needs assessment indicated a need for a much larger than the amount pledged at Tokyo. CARE international have stated: "The World Bank determined in January 2002, that, as a "basecase', Afghanistan would require $\$ 10.2$ billion over five years - about twice that actually pledged in Tokyo. Most experts concede that it will take considerably more than that". ${ }^{33}$

16. The fact that only a few of the Tokyo pledges covered a period of more than two years has made long term planning difficult. ${ }^{34}$ Multi-year pledging is crucial to provide adequate resources for future years and predictable funding to allow a rational allocation of resources. Regardless of the immediate humanitarian imperative, long-term commitment is important to meet the international community's aims of ensuring long-term security and stability. Given the clear need for more money over longer periods and the greater availability of information for conducting needs analyses, we were reassured to hear that DFID anticipates further pledges for Afghanistan in the future. Chris Austin told us: "In terms of has Afghanistan got enough at the moment? Yes, to start with, but it was only ever seen at Tokyo as the first stage". ${ }^{35}$ However, there are worries, which the Committee

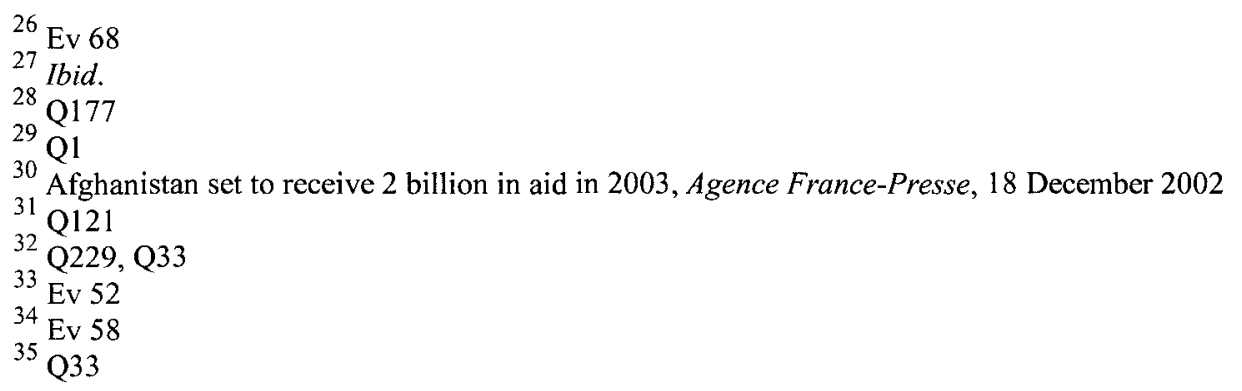


shares, that there is a planned reduction in DFID spending on Afghanistan next year. ${ }^{36}$ Although DFID has confirmed that it is on track to disburse its $£ 200$ million pledge over five years, disbursement of the money has been front-loaded and so commentators have expressed concern that the amounts will decrease next year and throughout the rest of the five years. ${ }^{37}$

17. One of DFID's great advantages is the flexibility which it has to move its money across departments, depending on extra or growing need. ${ }^{38}$ Clare Short would not be drawn on specific spending commitments, stressing that the money had to be based on a needs assessment and on the absorptive capacity of those institutions in Afghanistan which would be tasked with delivering the services. DFID plans to disburse $£ 65$ million of its pledge this year ( $£ 50$ million has already been disbursed) and will discuss future support plans and pledges with the Transitional Administration at the March 2003 Development Forum. ${ }^{39}$ There needs to be a rolling programme of pledging measured against progress on the ground in Afghanistan, to give all donors a chance to demonstrate their continuing commitment and to ensure that they will not leave Afghanistan as a job half completed. There should also be a timetable within which the international community aims to hand over areas of responsibility to the Afghan Transitional Administration.

\section{The balance of spending: from humanitarian relief to reconstruction and development}

18. At the time that money was pledged in Tokyo no distinction was made between spending on humanitarian relief and spending on reconstruction. When lives are at risk spending on humanitarian relief has to take priority, but reconstruction is fundamental to dealing with food security and vulnerability in the long term. Without investment to address the underlying causes of the humanitarian crisis, there can be no expectation of Afghanistan breaking out of the downward spiral. The British Agencies Afghanistan Group (BAAG) told us that the Afghan agricultural economy was not currently capable of supporting the population and that labour migration and opium production acted as safety valves for some of the vulnerable. ${ }^{40}$ Creation of viable livelihoods and development of the Afghan economy are therefore key to resolving the problems of food crisis in the long term. Although some work on reconstruction projects such as road building has now started, there remains an imbalance in spending which is tipped toward humanitarian relief. ${ }^{41}$ Many witnesses spoke of the need to redress the balance of spending between humanitarian and reconstruction as part of the necessity of securing enduring, long-term commitments from donors. ${ }^{42}$ Islamic Relief commented that:

"Right now, there is one kitty, so to speak, which is having to be split between both humanitarian and reconstruction needs and, as always, humanitarian needs are seen to be taking precedence because that is tangible, it is visible, when people die, you see them. If the road is not reconstructed this month compared to saving a life, well, let us reconstruct the road next month. That is how the split has been done". ${ }^{43}$

Afghan Ministers were particularly critical of the imbalance between humanitarian and reconstruction assistance. They argued that humanitarian assistance addressed symptoms

\footnotetext{
${ }^{36}$ Q207

${ }^{37}$ Ev 117, Q208

${ }^{38} \mathrm{Q} 213$

${ }^{39} \mathrm{Ev} 117$

${ }^{40} \mathrm{Q} 183$

${ }^{41} \mathrm{Q} 36$

${ }_{42} \mathrm{Q} 185$

${ }^{43}$ Q144
} 
not causes and that the huge proportion of assistance (about 25 per cent) which was spent on food aid "is only postponing death rather than strengthening lives and livelihoods". ${ }^{44}$

19. There are still large numbers of vulnerable people in Afghanistan and there is a continuing need for spending on humanitarian relief. Distinguishing humanitarian relief from reconstruction spending is no simple task. Different donors have differing perceptions of the breakdown of humanitarian and reconstruction spending contained in their contributions. Some activities, such as provision of a supply of drinking water, can be categorised as both humanitarian and reconstruction, depending on the donor. ${ }^{45}$ The problems involved in separating humanitarian and reconstruction spending also make it difficult to estimate how much has been spent on each. About two-thirds of the UK's spending to date has been on humanitarian relief. ${ }^{46}$

20. Differentiating between funding for humanitarian relief and reconstruction could help to focus development on long-term reconstruction. If there were two separate pots of money and provided that the humanitarian relief is adequately funded, reconstruction work could progress without the moral dilemma of whether the funding should have been used elsewhere. CARE International told us that there should be: "Funds for both emergency work and reconstruction to be made available with urgency so that Afghans are not forced to choose between the two" ${ }^{47}$ But the Secretary of State saw the traditional divide between humanitarian and development assistance as an unhelpful polarisation of the argument. She was particularly scathing about complaints, especially from the Transitional Administration, that funding had been skewed towards humanitarian assistance. For her, such comments showed an immaturity about the responsibilities of government: "If six million of your people... need food daily... to think: 'someone else's job is the humanitarian and we want to build roads', shows a lack of grasp of the duty of government". ${ }^{48}$

21. If a clearer indication of the general purpose of funds (for reconstruction or humanitarian relief) were made at the time of pledging, it would be easier to ensure that enough funding is made available for each purpose. Sufficient funds must be available for both reconstruction and humanitarian relief and better information about needs will be important in determining how much money is required. We understand the problems involved in separating humanitarian and reconstruction spending but consider that DFID and the international community needs to have a clear strategy, or at least set out milestones, for moving from humanitarian relief towards supporting reconstruction and development. This could involve the prioritisation of humanitarian work which also provides long-term benefits such as the supply of clean drinking water.

\section{International comparisons}

22 . The $\$ 4.8$ billion pledged over $3-4$ years is small in relation to the total needs of a country recovering from over two decades of conflict destruction and drought. Inevitably, many commentators have compared aid levels and disbursements in Afghanistan with recent post-conflict settings in other countries. Tokyo pledges were based on calculations made using comparison with the reconstruction of Bosnia. In Kabul and later at Westminster, Afghan Ministers spoke with one voice when it came to making the comparison between Afghanistan and other recent, post-conflict countries to demonstrate that levels of aid to Afghanistan are relatively low: "For example in Bosnia per capita assistance over five years was around $\$ 328$, Kosovo $\$ 288$, East Timor $\$ 175$, Rwanda

\footnotetext{
${ }^{44} \mathrm{Q} 1$

${ }_{45} \mathrm{Q} 164$

${ }^{46} \mathrm{lbid}$.

${ }^{47}$ Ev 52

${ }^{48}$ Q209
} 
something similar. In Afghanistan in 2002, based on pledges which have been made, the per capita figure is $\$ 75$; over five years it is roughly $\$ 40 " .{ }^{49}$ But the Secretary of State described such comments as unjustified and unattractive carping. She rejected the comparison with other countries because "a dollar in the Balkans is worth less than a dollar in Afghanistan". ${ }^{00}$ Tom Phillips of the Foreign and Commonwealth Office also stressed that the different purchasing power of a dollar in different countries meant that such per capita comparisons could be misleading. ${ }^{51}$

23. The criticisms of international comparisons offered by the Secretary of State certainly apply where the spending is on humanitarian relief for, say, the purchase of food or tents from local sources. But money spent on reconstruction, whether technical assistance for institution building or for major infrastructure projects is spent on consultants and engineers in international markets. The Programme Director of CARE International stated: "The vast majority of the costs of reconstruction efforts are not locally incurred and I think that the appeal to the fact that things are cheaper in Afghanistan is not [a] very strong argument to explain away the order of magnitude difference between the resources made available to Afghanistan and to other places". ${ }^{52}$ CARE International were emphatic that reconstruction needs in Afghanistan were significantly higher than in Rwanda, Bosnia, Kosovo or East Timor. Afghanistan's economy was at a standstill with core infrastructure destroyed on a massive scale. No other country had more mines and unexploded ordnance. ${ }^{53}$ Development Initiatives told us that per capita figures were generally calculated using the total population of a country rather than the total number of people affected by a crisis. ${ }^{54}$ As a result, the size of a country's population has a significant impact on the per capita calculation and it is not likely to indicate the average amount spent on each affected person, but rather the average across the whole population. But the value of such international comparisons was not dismissed out of hand and in terms of assessing how much more money might be needed for Afghanistan, Development Initiatives have resorted to comparison with overall aid sums for countries such as the former Yugoslavia and Rwanda. ${ }^{55}$ As a final comment, we have already noted in paragraph 12 that Chris Austin of DFID described the Tokyo money as an estimate based on other post conflict situations.

\section{The way money is channelled}

24. Aid from donors is channelled into Afghanistan in a variety of ways. Not all of the money pledged is spent in Afghanistan but, of that which is, a proportion is spent by donors directly through programmes which the donor runs and manages. For example, DFID has directly funded a $£ 3$ million project aimed at developing capacity within the Transitional Administration. ${ }^{56}$ Donors also channel some of their contributions through implementing partners, either NGOs or the United Nations Agencies. Most of the money DFID channels through the UN is disbursed directly to UN Agencies rather than through the UN coordination mechanism, UNAMA (United Nations Assistance Mission in Afghanistan). ${ }^{57}$ A further mechanism for channelling funds is the Afghanistan Reconstruction Trust Fund (ARTF) which is a multilateral trust fund operating to channel assistance to the Afghan government. ${ }^{58}$ The ARTF is administered by the World Bank and has a Management

\footnotetext{
${ }^{49} \mathrm{Q} 1$

${ }_{51}^{50} \mathrm{Q} 29$

${ }^{51} \mathrm{Q} 33$

${ }_{52} \mathrm{Q} 136$

53 Background paper: Rebuilding Afghanistan: A Little Less Talk, a Lot More Action, CARE International in Afghanistan: Policy Brief. Submitted by CARE International. Not printed

${ }^{54} \mathrm{Q} 160$

55 Q159

${ }_{57}^{56} \mathrm{Ev} 15$

${ }^{57} \mathrm{Q} 45$

${ }^{58}$ Ev 68
} 
Committee consisting of the Asian Development Bank, the Islamic Development Bank, UNDP and the World Bank. ${ }^{59}$ The Afghan Ministry of Finance is also represented on the Committee. ${ }^{60}$ This Committee meets regularly to review available monies, the government's preferred use of funds and to agree allocations. There is also a Donor Committee on which all donors are represented which provides policy guidance and can earmark funds for specific activities. ${ }^{61}$ Development Initiatives described the ARTF as a means by which donors could support the Afghan Transitional Administration but with the safeguard of having the fund run by the World Bank. ${ }^{62}$ Almost 55 per cent of UK disbursements to date have been channelled through the UN, a further 15 per cent has been channelled through NGOs and 14 per cent has been channelled through the ARTF and its predecessor, the Afghan Interim Authority Fund. ${ }^{63}$

25. Some of the money pledged at Tokyo was in the form of concessional lending. The Afghan authorities, the aid community and commentators were not aware of this at the time of pledging. ${ }^{64}$ The Transitional Administration has been slow to draw down on these loans. We heard during our visit to Afghanistan that this reluctance was partly related to concern over repayments but may also be linked to a desire to maximise the amount of grant aid received. ${ }^{65}$ Some witnesses sympathised with Afghan reluctance to indebt itself but it was also pointed out that the loans on offer were on excellent terms and would not have a negative impact on the developing economy. ${ }^{66}$ However, there is a distinction between borrowing for capital projects, which is widely seen as acceptable, and borrowing to cover recurrent costs which is unsustainable in the long-term. After an initial reluctance, the Transitional Administration has recently declared its willingness to draw down on some of the loans it has been offered ${ }^{67}$ The Secretary of State told us that a programme to clear Afghanistan's debt arrears was already underway and would provide Afghanistan with a clean slate for borrowing from International Financial Institutions such as the World Bank and Asian Development Bank: "They can then borrow hundreds of millions of dollars and get all the technical expertise that goes with it .... there is something good about a country taking responsibility for its own long-term concessional borrowing .... you have to make sure it produces results [and] ... it provides that sense of being responsible for their own future." ${ }^{, 98}$ We believe that the use of loans, as part of a managed economic strategy, will allow the Afghan economy to develop, decreasing its reliance on grant aid and helping to demonstrate that Afghanistan: "is a place where investors can put money with confidence, knowing that they can get a return on their investment and they will be able to repatriate the profits" ${ }^{69}$ Sovereign debt is another matter, however. Afghanistan has massive debts to the Paris Club, mostly to Russia, a country which they may not be very keen to repay. A Paris Club clearance will be necessary to normalise Afghanistan's finances and pave the way for a level of inward investment which the Transitional Authority is hoping for. ${ }^{70}$

\footnotetext{
${ }^{59}$ Background paper: Funding for Afghanistan-a quick guide to institutions and funds, Afghan Aid Flow Information Bulletin, 9 October 2002 submitted by Development Initiatives. Not printed

${ }^{60} \mathrm{Q} 223$

${ }^{61}$ Q174, Background paper: Funding for Afghanistan-a quick guide to institutions and funds, Afghan Aid Flow Information Bulletin, 9 October 2002 submitted by Development Initiatives. Not printed

${ }^{62} \mathrm{Q} 174$

${ }^{63} \mathrm{Ev} 68$

${ }^{64} \mathrm{Q} 1$

${ }_{65}$ Meetings with Asian Development Bank and European Commission Representatives, Kabul, October 2002

${ }^{66}$ Ev 52, Q38

${ }^{67} \mathrm{Q} 38$

${ }^{68} \mathrm{Q} 227$

${ }^{69} \mathrm{Q} 38$

${ }^{70} \mathrm{Q} 227$
} 


\section{Efficiency}

\section{The Afghan Transitional Administration}

26. The Afghan Transitional Administration's recurrent budget for this year was set at $\$ 483$ million with $\$ 400$ million of this being dependent on external finance. ${ }^{71}$ The Transitional Administration receives this funding partly via the Afghanistan Reconstruction Trust Fund but was also expected to obtain 50 per cent of its running costs from domestic revenue sources in the regions. ${ }^{72}$ DFID have allocated $£ 5$ million of its total budget for Afghanistan to eventually go directly to the Transitional Administration. ${ }^{73}$ At the time of our visit, we were told by the Finance Minister that 80 per cent of the revenue budget was aid and the corresponding figure for the development budget was 100 per cent. The Transitional Administration's recurrent budget seems very low when compared with the annual budget for a British local authority: Birmingham City Council's expenditure for the 2000-01 financial year was $£ 1,121.6$ million. $^{74}$ So not only is the Transitional Administration's budget comparatively small for the massive task at hand, but there have also been shortfalls in its funding, partly arising from the failure to generate regional tax and customs revenues. ${ }^{75}$

27. Furthermore, nearly 80 per cent of this budget is taken up with the civil service payroll (including military and police expenditures). ${ }^{76}$ The lack of resources has posed a considerable problem for the Transitional Administration whose Ministers have been vociferous in calling for more funds. ${ }^{77}$ Not only is the Transitional Administration underfunded, it also has a credibility problem: Afghans do not see it delivering public services or reconstruction. Dr Abdullah, Minister for Foreign Affairs told us: "one big risk which this government is facing is that it is losing credibility among the people. Because of the Bonn agreement, of the Tokyo conference, especially after the Loya Jirga, the expectations of our people were raised to a high level". ${ }^{78}$ The Afghan Transitional Administration struggles to maintain its credibility because it is under-resourced and not seen by Afghans as delivering those basic public services that people expect from their governments, let alone broader reconstruction. ${ }^{79}$ It is essential that the Transitional Administration establishes it legitimacy; the future stability of the entire country depends on this Administration's ability to govern until an elected government takes over.

28. The loss of legitimacy arises partly because the Administration has insufficient control over the way money is spent and aid providers are keen ensure that they are given credit for their programmes. Donors have their own funding battles to fight and Karl Habro Head of the Kabul European Commission Office argued that unless donors were given credit for their support for the recurrent budget (as well as for large infrastructure projects), donors would cease to fund such activities. ${ }^{80}$ But ultimately such approaches only undermine the Administration's authority as its lack of involvement is all too clear for the public to see.

\footnotetext{
${ }_{72}^{71} \mathrm{Q} 45$

$72 \mathrm{Ev} 80$

${ }^{73}$ Ev 80

${ }_{75}^{74}$ Birmingham City Council Accounts 2000-2001

${ }^{75}$ Ev 80

${ }^{76} \mathrm{Q} 45$

${ }_{78}^{77}$ 2

78 Ibid.

${ }^{79}$ Ev 80

${ }^{80}$ Meeting with the Committee in Kabul, October 2202
} 
29. In the early part of 2002 DFID was, along with other donors, the UN and NGOs, involved in supporting a number of Quick Impact Projects (QIPs), as part of helping to underpin the authority of central government by showing that benefits were being brought to local communities. Although the presence of international aid workers is apparent to Afghans, some projects, such as those seeking to build capacity in state institutions are "invisible". This has led to a negative public perception of international agencies as spending too much on their own costs and not enough on their beneficiaries, and may also be behind donor emphasis on "visible" QIPs. ${ }^{81}$ Hence DFID's involvement in a Kandahar education project with Islamic Relief. ${ }^{82}$ But even QIPs can be slow to set-up and NGOs reported that funding opportunities from DFID were skewed towards a focus on QIPs. ${ }^{83}$ There should be no trade-off between QIPs and investment in longer-term projects. The challenge for donors is to support the Transitional Administration in taking forward its programmes, scaling them up and making donor interventions more strategic.

30. There has been criticism, largely from the Afghan authorities, of the slow rate at which funds have been released. ${ }^{84}$ This arose partly from misleading disbursement figures given to the Afghanistan Assistance and Coordination Authority. ${ }^{85}$ Nevertheless, both Development Initiatives and UNAMA told us that disbursement was taking place quite quickly by comparison with other post-conflict situations. The Special Adviser to the Special Representative of the UN Secretary General said that: "This is a world record in terms of both generosity of donors, the speed with which funds have been made available, and the speed with which certain funds have been spent on the ground" ${ }^{86}$ However Judith Randel of Development Initiatives cautioned that "disbursement" didn't necessarily mean that money had been spent but was rather a first step "on a path to delivering the benefit in Afghanistan". ${ }^{87}$

31. The root cause of the Transitional Administration's dissatisfaction appears to lie in the fact that the money pledged at the Tokyo 'International Conference on Reconstruction Assistance to Afghanistan' was generally thought to be for reconstruction but has in practice been largely swallowed up by humanitarian relief. The Afghan Minister for Rural Development and Reconstruction said in oral evidence:

"The composition of the $\$ 4.5$ billion [pledged at Tokyo] was not defined. It is meant to be reconstruction assistance. There is a humanitarian situation which has to be addressed as well. Now we have ended up with a situation where 70 per cent of the money has gone to the humanitarian side of it, which has to be addressed, but humanitarian assistance is not reconstruction assistance". ${ }^{88}$

That it was not made clear that part of the Tokyo pledge was in the form of loans was also a cause of complaint. One Minister told the Committee: "Some countries which made pledges at the Tokyo conference had not defined the fact that they meant credit as well as grants so later on we found out that some countries' pledges were only 50 per cent grants". ${ }^{89}$ The core problem is that with reduced funds available for reconstruction and the fact that disbursement does not immediately translate into spending, there is not enough

${ }^{81}$ Ev 58, Ev 80

${ }^{82} \operatorname{Ev} 58$

83 Ibid.

${ }_{85}^{84} \mathrm{Q} 1$

${ }^{85}$ ISAF contributions and refugee assistance programmes within donor countries were included in disbursement reports to the AACA. This was raised with the Committee by European Commission Office Representatives in Kabul in October 2002

${ }_{86}^{8} \mathrm{Q} 91$

${ }_{88}^{87} \mathrm{Q} 161$

${ }^{88} \mathrm{Q} 1$

89 Ibid. 
visible reconstruction happening on the ground in Afghanistan. ${ }^{90}$ The British Agencies Afghanistan Group reported that: "Negative views of the international community have been increasing as visible signs of assistance are lacking".

32. A solution to the Transitional Administration's credibility problems would seem to be to channel more resources directly through the Transitional Administration. This would certainly ease its current dissatisfaction. But donors have been concerned about the Transitional Administration's lack of capacity to absorb large amounts of funding or to deliver public services. Clare Short told us that the Transitional Administration was underspent on the resources to which it already had access. ${ }^{92}$ DFID's Chris Austin stated in evidence : "I think it is fair to characterise the Afghan public services as poorly paid, poorly organised and, probably, in large measure poorly qualified because they have been operating either in a vacuum for several years or people's skills have atrophied a little bit". ${ }^{93}$ The problem lies not only in in skills shortages but also, as was seen on the Committee's visit, in the lack of such basic equipment as photocopiers, filing cabinets and even desks. Afghan Ministers know that there is a problem but are concerned that it is used as an excuse not to deal through the Transitional Administration . ${ }^{94}$

33. The Transitional Administration overstates its case. It is sometimes said that Hamid Karzai is, in effect, just the Mayor of Kabul. The Secretary of State put it even more strongly, stating that: "The writ of the Afghan government does not reach outside Kabul at all. If all the resources had gone to them people would have starved." 95 She advocated a partnership handover under which, as security outside Kabul improves, the Transitional Administration would link to the NGOs and UN's capacity to deliver and gradually take on the management of that and make it part of a government delivery system. ${ }^{96}$ As things stand at present, the Secretary of State is correct in saying that the Transitional Administration cannot deliver outside of Kabul and it is NGOs, the UN and, where they are implementing programmes directly, donors, that are the deliverers. The question is how to perform the delicate balance between acknowledging the UN, NGO and donor role, ensuring that services are delivered through them and, on the other hand, not undermining the fragile legitimacy of the Transitional Administration while seeking to build its capacity to take over the delivery of services. There is a tension between the desire to have Afghan-led development and the need to channel resources where there is the capacity to spend them.

34. For DFID, civil service reform is the priority. Until reform has begun to be tackled, donors could end up funding a large number of poorly paid civil servants to deliver very little. Clare Short said that: "the Taliban civil service, the previous communist civil service, and anyone else who thought they were in the civil service, all turned up just before Tokyo, and then the government said, "we've got to pay salaries; that proves we've got some authority." 97 She went on to say that DFID could not continue putting resources into Afghan budgets without reform of the civil service. ${ }^{98}$ The Committee heard during its visit of overstaffing as well as large numbers of "ghost workers" operating in both the civil service and the military, who were on the payroll but were not working. Mukesh Kapila (UN) described payment of ghost workers as a kind of social security:

\footnotetext{
${ }^{90} \operatorname{Ev} 58, \operatorname{Ev} 80$

91 Ev 80

$92 \mathrm{Q} 209$

$93 \mathrm{Q} 45$

${ }_{95} \mathrm{Q} 2, \mathrm{Q} 149$

${ }_{95} \mathrm{Q} 209$

96 Ibid.

${ }^{97}$ Q209

98 Ibid.
} 
"In a sense though, this is not necessarily said officially, the payment of civil service salaries is like a social safety net, so it is obvious that the tens of thousands of civil servants who have been paid are not working fully or effectively, and undoubtedly the payroll is inflated. The Taliban, for example, created a lot of civil servants in the last months in power and it is a very onerous business trying to distinguish between real civil servants and fake. However, even fake civil servants have families and there are two ways of looking after them: they can get some money which effectively forms a social security, $\$ 30$ a month, or they can go to the charitable sources for food and shelter and so on that are being made available". ${ }^{99}$

This only strengthens the argument for civil service reform. In our meeting in Kabul with Nigel Fisher of UNAMA, we were told that, of those civil servants who had skills, most were in the mould of a soviet-style centrally planned government; there was a lack of experience in administration, audit and standard setting. Work on reform is underway with DFID helping to define the payroll and create documentation systems to justify the payment of salaries. The EC is also involved and has identified leaders of clusters of reform to whom realistic salaries are being paid. But there is a long way for the Transitional Administration to go from sorting out who is on the payroll and setting up procurement and financing systems to being in a position to deliver effective services to its people.

35. The Afghan Transitional Administration is not wholly lacking in capacity, as its production of the National Development Framework (NDF) demonstrates. DFID has commended the NDF as a good start in defining the objectives of a pro-poor strategy. ${ }^{100}$ But donor and Afghan concerns mean that capacity and institution building will need to be given a higher priority and quickly if the Transitional Administration is to govern effectively and plan for the longer term. The Transitional Administration fears that unless a greater share of resources are channelled through Afghan institutions, capacity may never develop. As Hanif Atmar, Minister for Rural Development and Reconstruction told the Committee:

"Over 90 per cent of the resources have gone through non-state entities and this will be counter productive to the state building project... there is still a kind of reluctance to consider channelling resources through the National Development Budget. This is not helpful in terms of the capacity building of the government and the government's ability to ensure equity in resource distribution across the country through a unified policy". ${ }^{101}$

It was also pointed out that without channelling more money through the Transitional Administration, it would be difficult to identify where capacity needs are greatest. $\mathrm{Mr}$ Atmar commented: "Unless we have resources, unless we have water in the pipes, we will not know where the leakages are in the pipes". ${ }^{102}$

36. Clare Short described Mr Atmar's comment as: "a really foolish statement". In her view any institution should know whether it had proper accounting systems and auditing before money is put into it. ${ }^{103}$ But we think that Hanif Atmar perhaps has a point. The Secretary of State has frequently referred to DFID's wish to spot reformers within governments and to work with them. She herself described the progress which the Finance Ministry had made with auditing and financial accounting systems. ${ }^{104}$ Hanif Atmar's ministry for Rural Development and Reconstruction was in her own words "a good

\footnotetext{
${ }_{100}^{99}$ Special Adviser to the UN Special Representative, Q98

${ }_{100}^{10}$ Ev 117

${ }^{101} \mathrm{Q} 1$

102 Q13

${ }_{103} \mathrm{Q} 219$

104 Ibid.
} 
Ministry". DFID's Chris Austin told us : “The next stage of Afghan's development will be to prime the Government's own budgets so that it can manage its finances and its spending activities more directly". ${ }^{105}$ In January 2003 the successful installation and operation of a financial management information system was announced following a two year, World Bank financed project to help the Transitional Administration upgrade its accounting system. ${ }^{106}$ We understand the Secretary of State's concerns about the Afghan Transitional Administration and echo her call for urgent civil service reform. But we also think that putting some money into the parts of the Administration which have reformed would not necessarily be a wasteful exercise. It would help identify where weaknesses lie. At some point soon donors have to take a risk and be willing to allow more funds to be channelled through those areas in which the Transitional Administration has demonstrated significant progress.

\section{Coordination}

37. Written evidence pointed to the need for better co-ordination between donors and aid organisations but in particular for coordination with the Afghan Transitional Administration. ${ }^{107}$ Lakhdar Brahimi's ${ }^{108}$ request for a "light footprint"approach is connected to a recognition by the international community of the importance of Afghan involvement in setting policy and spending priorities. Islamic Relief felt it was vital not to implement projects outside the National Development Framework in order to avoid setting up the parallel structures that have often been seen in reconstruction programmes elsewhere. ${ }^{109}$ But these parallel structures are already in place and inevitably so given the Transitional Administration's lack of control outside Kabul. ${ }^{110}$ NGOs and UN agencies are of necessity the deliverers of basic public services outside Kabul. NGOs have told us that in the long term they want to focus on their own development projects rather than on the delivery of basic public services. ${ }^{111}$ At the moment this is unlikely. The British Agencies in Afghanistan Group commented that:

"the perception and the reality, is that the Afghan government does not have actual control over the funds being made available for Afghanistan. The recent insistence by the ATA that it should have a say in the content of the next UN appeal for Afghanistan is indicative of its unhappiness with the status quo. And in particular, with the fact that the UN is, as the ATA perceives it, operating as a parallel government". ${ }^{12}$

38. The perception that aid organisations are creating parallel structures to the Transitional Administration reinforces the need to coordinate spending priorities so as to build the credibility of the Transitional Administration as it takes greater ownership of development and reconstruction. The National Development Framework provides a fundamental pillar in increasing Afghan ownership of reconstruction and is in keeping with the "light footprint" approach. Such an approach has been challenged as confusing operational means with strategic ends. ${ }^{113}$ UN agencies and NGOs are of necessity are destined to play a major role in reconstruction because there is not the current capacity for it to be an entirely Afghan-led exercise. Nevertheless, there is still a need for greater

\footnotetext{
105 Q37

106 BearingPoint delivers Financial Management System to Government of Afghanistan, PR Newswire Europe, 02 January 2003

${ }_{107}$ Ev 58

108 Special Representative of the UN Secretary General

$109 \mathrm{Ev} 58$

$110 \mathrm{Q} 209$

$111 \mathrm{Q} 138$

112 Ev 80

${ }^{113}$ Strategic Coordination in Afghanistan, Nicholas Stockton, Afghanistan Evaluation and Research Unit, August 2002, Q50
} 
coordination with the Transitional Administration. DFID seem to be aware of this and have told us that coordination is being facilitated through the launch of the next $U N$ consolidated appeal as an integral part of the National Development Framework. ${ }^{114}$ We heard criticism of coordination arrangements. ${ }^{115}$ Endless coordination meetings often involve the same actors and serve to increase transaction costs. ${ }^{116}$ What is needed are not more coordination meetings but rather a rationalisation of existing procedures. There is some evidence that this is happening; meetings of the Afghanistan Reconstruction Steering Group, the Afghanistan Support Group and the Implementation Group will be brought together under a "Development Forum" model in March 2003. ${ }^{117}$ In December 2003 Norway announced that the Afghanistan Support Group which it chaired was to be discontinued and responsibility for coordination handed over to the Afghan Transitional Administration. We welcome the transfer of the Afghan Support Group's responsibilities to the Afghan Transitional Administration as part of the move towards a development forum informed by and involving consultative groups.

39. Co-ordination is also an issue for UNAMA. UNAMA was established in March 2002 and is led by Lakhdar Brahimi. Under the Bonn Agreement it has a twelve month renewable mandate to fulfil tasks entrusted to the UN. It has special responsibilities in the areas of national reconciliation, human rights, rule of law, the role of women and humanitarian affairs vis $\grave{a}$ vis co-ordinating $\mathrm{UN}$ relief, recovery and reconstruction effort within the UN system and with the Afghan Transitional Administration. During our visit to Afghanistan we saw little evidence of UNAMA stamping its strategic mark on UN activities and found instead that each agency seemed to have its own strategy. The DFID memorandum states: "There is also a clear lack of capacity within UNAMA to take a more pro-active role in assisting the Afghans to plan and monitor reconstruction". ${ }^{118}$ DFID told us that they tend to fund UN Agencies directly, rather than through UNAMA ${ }^{119}$ UNAMA did not see this as a problem. ${ }^{120}$ We are concerned that UNAMA is not, in practice, coordinating the strategies of the UN Agencies and as such is unable to act as an "effective bridge between the international community and the will of the Transitional Administration". ${ }^{121}$ The UN should be given due credit for its work on what is a difficult task but, in line with its mandate which it was given at Bonn, the UN should consider how it can improve the coordination which it is providing. UNAMA should be playing the lead role in countering the perception that the UN is operating as a parallel structure to the Afghan Transitional Administration rather than an assistant to and advocate for Afghan-led reconstruction.

\section{The Role of NGOs}

40. NGOs have been providing services across all sectors in Afghanistan throughout the 23 years of conflict and, in some cases, for even longer. The larger NGOs have provided substantial public services, such as health and education, where there would otherwise be none. They have also acted as implementing partners to the UN within their own mandates, carrying out the work on their behalf to reach the vulnerable. At the moment, in the absence of public service delivery through the Afghan Transitional Administration, NGOs remain the main service providers. There has been a perception that there are too many NGOs. While those with long-term experience remain, there was an influx after September 11th and co-ordination has, at times, been difficult. DFID's Chris Austin said in evidence: "the approach the UK has followed, which

\footnotetext{
114 Ev 117

115 E.g. Ev 58

116 Q50

117 Ibid.

118 Ev 15

119 Q45

${ }^{120} \mathrm{Q} 87$

${ }^{121} \mathrm{Q} 83$
} 
has mirrored others, has been to finance UN Agencies who may be subcontracting to NGOs or other private sector people locally, to contract them to do the implementation direct because they have got the capacity to do that". ${ }^{122}$ The Secretary of State thought that the current situation was satisfactory and called for greater utilisation by the Transitional Administration of NGOs and UN Agenciesas a delivery mechanism: "the government should link to the NGOs and the UN's systems capacity to deliver, and then start to manage that more; have an umbrella over the budgets and make that part of a government delivery system". ${ }^{123}$ But there is evidence that NGOs have problems with their role filling the gaps in delivery of public services. CARE International Director Raja Jarrah saw his long-term role as one of strengthening civil society rather than service delivery and capacity building - which all to often looked like gap-filling - emphasising that: "NGOs are an actor in development of their own right and are not simply an implementation agency for international donors". ${ }^{124} \mathrm{Mr}$ Jarrah neatly summarised his position stating: "For understandable reasons, NGOs so far in Afghanistan have been used mainly in a service delivery role and I can see that continuing for the immediate future, but I would like to emphasise that NGOs do not see their role as being solely that nor are we there simply to build the capacity of actors who currently cannot rise to their responsibilities. NGOs do have a long-term future in Afghanistan and it looks very different from the role that they are fulfilling at the moment". ${ }^{25}$

\section{Transaction costs}

41. During the visit we heard criticism of high overheads incurred by, in particular, the $\mathrm{UN}$ from spending on vehicles, high salaries and generous per diems for international staff. The high visibility of the UN and international NGOs leads, not surprisingly, to some resentment and to the sense that the most visible sign of foreign aid is aid workers driving white land cruisers around Kabul. ${ }^{126}$ International aid workers are seen by Afghans as having a comfortable lifestyle in comparison with their own which is affected by the lack of basic provisions of healthcare, water, sanitation and electricity for the general population. Indeed, there have been cases of attacks on aid workers. The British Agencies Afghanistan Group (BAAG) told the Committee in its written submission: "Feelings are running high about perceived consumption of aid monies by the United Nations and NGOs for their vehicles, offices and staff". ${ }^{127}$ All aid delivery organisations carry overheads: for DFID and other donors, the essential overhead cost of security-the close protection team-distorts what would otherwise be standard overhead costs. But DFID's Chris Austin drew a distinction between those overheads and "transaction costs" which resulted from tied aid and procedures that require the Transitional Administration to negotiate separate projects and contracts for each activity. ${ }^{128} \mathrm{He}$ explained how such costs were incurred:

"each of the donors, including DFID, would have its own project procedures to follow and reporting and accountability requirements to meet which imposed transaction costs on us and implementing agencies... As we move forward with the National Development Framework, any money provided to Afghanistan now that involves the Government is going to require a discussion with Government, exchanges of letters of understanding and meetings and so on, and all those are transaction costs". ${ }^{129}$ 
42. Transaction costs are not, therefore, simply bureaucratic overheads but in many cases arise from those requirements for accountability, evaluation of projects and coordination with other agencies, on which donors insist. Transaction costs may also arise from payment of one agency by another, meaning that some funds never reach Afghanistan at all but remain in Washington or Geneva. An example of this is payment by all agencies and NGOs to the WFP which runs all flights in and out of Afghanistan. Transaction costs are also incurred by coordination itself. A recent report by the AREU on strategic coordination in Afghanistan has commented: "the coordination arrangements as practised appear to generate dysfunctional inter-agency transaction costs". ${ }^{130}$ A further complication emerges when policy dialogue is taken into account. DFID tries to keep a light administrative touch on the funds which it channels to the Transitional Administration and implementing agencies. Nevertheless, as Chris Austin explained, DFID has a large team engaging with the Afghans and other agencies on policy dialogue, not in managing money. He rightly posed the question: was that team an overhead or a development benefit? ${ }^{131}$

43. We recognise that Afghanistan is a particularly difficult operating environment and so transaction costs may be higher as a result. However, the presence of large numbers of aid workers has had an inflationary impact on rents and salaries. Channelling of resources through the UN agencies and NGOs has meant that they have to either bring in more expatriate staff (at high cost) or recruit locally. This has meant, in the words of Hanif Atmar, that "even the little brain that we have in the government goes to the UN and the NGOs and we will never have it". ${ }^{132}$ Staff working for the UN or NGOs receive much higher salaries that the Transitional Administration can afford to pay. Comparisons between salaries of aid staff and Afghan Ministers and civil servants may have served to produce a negative public perception. ${ }^{133} \mathrm{Dr}$ Shaheedi, Deputy Minister for Reconstruction, contrasted his ministerial salary of $\$ 50$ per month with (international) NGO salaries of $\$ 3$ 4000 per month. Clare Short saw the securing of realistic salaries for Afghan ministers as part of institution building. But she had little sympathy for what she saw as attacks on the UN system and considered it appropriate that international aid workers should receive international salaries. ${ }^{134}$ There needs to be an element of realism here; the provision of key services in a country where government capacity to deliver is restricted to the capital city, if that, cannot be carried out by gap-year students. But even so there needs to be a close monitoring of overheads, not just for reasons of financial probity but also because of the perception which they can create among the Afghan people. It is right that international aid workers receive international salaries but local employees should also receive fair pay which, at the very least, lifts them out of poverty.

44. Information on average levels of transaction costs in different aid situations is hard to come by but approximate calculations are that NGOs spend roughly 10-15 per cent on overheads and transaction/administrative costs: although this figure varies depending on how such costs are defined. There is also a lack of information about exactly how much is being spent on transaction costs in Afghanistan and this partly relates to the lack of transparency beyond the first stage of funds being disbursed. Funds pass through many layers between being disbursed and spent. ${ }^{135}$ Development Initiatives told the Committee about a "lack of transparency once you get beyond the first stage of the disbursement and the transaction costs, because at the moment, if you wanted to find out exactly what had been spent as opposed to allocated towards being spent, it is incredibly difficult to do so, and so it is very difficult to hold people to account". ${ }^{136}$ In responding to the criticism of

\footnotetext{
${ }^{130}$ Strategic Coordination in Afghanistan, Nicholas Stockton, Afghanistan Research and Evaluation Unit (AREU), August 2002

131 Q225

132 Meeting with the Committee, Kabul, October 2002

$133 \mathrm{Q} 46$

${ }_{134} \mathrm{Q} 226$

$135 \mathrm{Q} 163$

${ }^{136}$ Q170
} 
high UN transaction costs Mukesh Kapila, Special Adviser to the UN Special Representative, told us that many of its staff had been seconded to work in the Transitional Administration and that their international salaries would fall into the traditional definition of a transaction cost but pointed out that "The rates of pay and the overheads are set by [UN] member states". ${ }^{137}$ Although precise figures are not available we have heard anecdotally that UN transaction costs are roughly estimated to be about 30 per cent. Keeping administrative costs and overheads down must be a priority for all donors but especially for those, such as the $U N$, which are not directly accountable to electorates. It is interesting to note that the Afghanistan Research and Evaluation Unit have interpreted the UN approach of leaving a light institutional footprint as being a "well intentioned and much needed initiative to control agency management costs". ${ }^{138}$ One way to address criticisms of high transaction costs would be to ensure full transparency in the spending following disbursement although it is important that any measures to increase transparency are resource neutral in their impact.

\section{The Afghanistan Reconstruction Trust Fund-A way forward?}

45. The ARTF was envisaged in Tokyo as providing co-ordinated financing of Afghanistan's reconstruction programme, including part of the operating budget of the Afghan Transitional Administration. The latter has been keen to see more funds channelled to it through the ARTF. Money in the ARTF, although designated to provide the Transitional Administration's recurrent budget, can also be used to fund priority sectoral investment. ${ }^{139}$ Directing the flow of money through the ARTF would not necessarily mean all of that money going straight to the Transitional Administration, which lacks capacity in many key areas. Instead, it might potentially mean that NGOs and UN Agencies could also bid for access to ARTF funding. As the Transitional Administration is represented on the ARTF Board and on the ARTF Management Committee, which agrees allocations, sending more money down this route would ensure that allocations were made in line with the priorities of the National Development Framework, thereby helping reduce the creation or strengthening of the parallel structures that undermine the Transitional Administration's credibility. Afghan Ministers wanted to enhance the national budget and told us: "we are keen to ask other donors to follow the example of DFID, which has taken a number of good steps towards that by contributing to the Afghanistan Reconstruction Trust Fund". 140

46. DFID itself is keen to see the ARTF as a major channel for pooling bilateral funding for Afghanistan, but is insisting that civil service reform must happen if the recurrent budget support is to continue through the ARTF. Witnesses saw the ARTF as an effective mechanism and seemed to support the use of the ARTF as a fund from which the Transitional Administration, NGOs and UN Agencies could all make bids for funds. ${ }^{141}$ The Transitional Administration sees the ARTF as a second best to direct budgetary support. Use of the ARTF as a common funding pot may also help to prevent the underspending about which the Secretary of State was concerned. ${ }^{142}$ If UN Agencies and NGOs were also bidding for funds from the ARTF, resources would naturally follow capacity and NGOs and Agencies could spend money not used by the Transitional Administration. As we have noted throughout the report, there is a tension between ensuring that money is spent where capacity exists on the one hand, and the need to demonstrate that the Afghans are in control through their agencies on the other. The ARTF is dominated by the major development institutions run by the donors. As such, it provides a channel for funding which should

\footnotetext{
${ }_{138}^{137}$ Q92

138 Strategic Coordination in Afghanistan, Nicholas Stockton, Afghanistan Research and Evaluation Unit (AREU), August 2002

39 Background paper: Funding for Afghanistan-a quick guide to institutions and funds, Afghan Aid Flow Information Bulletin, 9 October 2002 submitted by Development Initiatives. Not printed

${ }_{140}^{142}$

${ }_{141} \mathrm{Q} 122, \mathrm{Q} 150, \mathrm{Q} 172$

${ }^{142} \mathrm{Q} 209$
} 
safeguard donors' anxiety about money being spent properly. As Development Initiatives told us "If you are serious about supporting the government and you need that government face to be credible ... then you have, at some point, to put your money where your mouth is and, with appropriate safeguards, which the ARTF is supposed to provide, enable them to do that". ${ }^{143}$ We agree and recommend that greater use is made of the ARTF with the aim of it becoming the main pool of donor funding from which the Afghan Transitional Administration, UN and NGOs can bid for allocations. Use of the ARTF can solve the tension between, on the one hand, a wish to see reconstruction led by Afghans and for the international community to leave a "light footprint" and, on the other, the wish to move resources where there is the capacity to use them.

\section{SECURITY}

47. The history of conflict in Afghanistan over the last 25 years requires no repeating here. When we last reported on Afghanistan, the lack of security threatened the delivery of food aid; now it threatens reconstruction. Clare Short was emphatic about the role which security played as the sine qua non of civil society. She considered that development thinking had failed sufficiently to take into account the importance of the state retaining what should be its monopoly of violence. ${ }^{144}$ The "Voices of the Poor" exercise, which embraced 60,000 people in the sixty countries revealed security - not food or health-as the top demand worldwide of the poor. ${ }^{145}$

48. The problem of insecurity continues and aid providers operating in Afghanistan told us that the situation in some parts is deteriorating. ${ }^{146}$ The killing of the Afghan Minister of Civil Aviation and Tourism and the Minister of Planning in July 2002 and the attempted assassination of President Karzai in Kandahar in September 2002 demonstrate the vulnerability of the government and the lack of security. Regional rivalries, power struggles and continuing battles between coalition forces and the remanets of the Taliban are major causes of prevailing insecurity. ${ }^{147}$ There are now fears that the Taliban may be creeping back into Afghanistan. ${ }^{148}$ The flooding of the country with weapons during recent conflicts has fuelled the tendency to resort to arms as a means of settling disputes. The breakdown of control following the fall of the Taliban regime has also led to increasing crime, banditry and factional fighting in some areas. ${ }^{149}$ Poverty and the absence of an adequate police force or judicial system are the main causes of insecurity.

49. Persistent insecurity hampers humanitarian relief and is one of the main obstacles to reconstruction. ${ }^{150}$ NGO and aid agency workers have been placed in danger and access to some areas has been impossible. ${ }^{151}$ The uncertain environment in Afghanistan makes long-term planning difficult and may have affected the confidence of donors to invest. ${ }^{152}$ Christian Aid have suggested that the constant threat of insecurity has affected: "the level of monies that international donor agencies have delivered on". 153 Increasing security is not only vital to Afghanistan's reconstruction and development is also

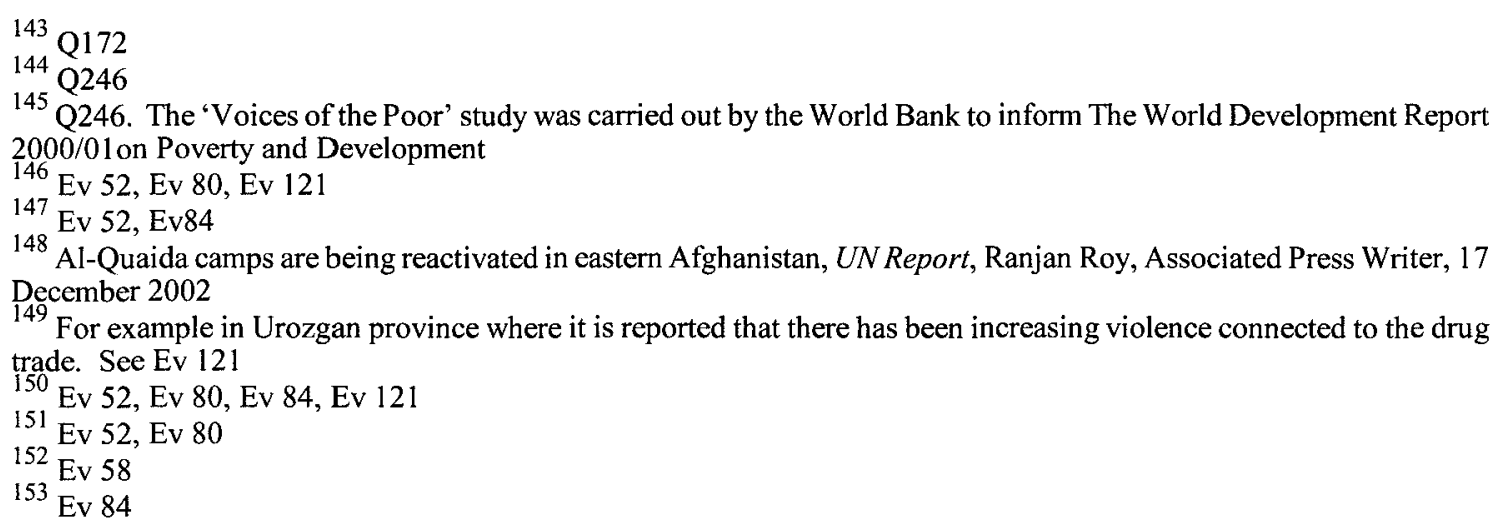


essential to reduce the substantial risk of Afghanistan reverting to civil war. ${ }^{154}$ Oxfam felt that a resurgence of warlords was noticeable, and was endangering the stability of Afghanistan and threatening to derail its transition from civil war". 155

\section{Regional power holders}

50. Historically, regional power holders have been prominent in Afghan politics and have competed for power and influence. Often referred to as "warlords", regional power holders may command large militias and have access to significant resources. ${ }^{156}$ Throughout Afghanistan's recent history, other countries, neighbours and those further afield, have interfered in local and national politics by arming and providing financial support to regional power holders, using civil war to fight their own proxy wars. ${ }^{157}$ The recent use of such tactics by the United States as part of the "war against terror" has given rise to talk of "Pentagon-created warlords". ${ }^{158}$ Some regional power holders have played an important role in delivering services to the population in their areas but there have also been cases of commanders associated with these regional power holders engaging in violent clashes and looting. ${ }^{159}$ During our visit to Afghanistan we were told that in some areas, warlords and local militias threatened NGO workers and in places skimmed off resources flowing through NGOs by levying a "tax" on their operations. ${ }^{160}$ Human Rights Watch have reported what they see as serious human rights abuses, most recently in the Herat area. ${ }^{161}$

51. The Bonn Agreement included the warlords; who were the people in the country with power. Most of Afghanistan's regional power holders were later incorporated into the Afghan Transitional Administration at the Loya Jirga in June 2002. ${ }^{162}$ The Transitional Administration is trying to incorporate the highest level commanders into the government and, at the same time, diminish their power in the regions. Some now occupy ministerial positions and in certain cases, such as that of Mohammed Fahim who controls much of the northeast of the country, they were made into Vice-Presidents. The President of the Transitional Administration had pursued a strategy of co-opting as many leaders and commanders as possible because their involvement has helped smooth the way to stability. Although theoretically acting as a mechanism for provincial government, regional leaders have not always made their allegiance to the Transitional Administration apparent in practice. ${ }^{163}$ Some leaders have been reluctant to return their revenues to the Transitional Administration. ${ }^{164}$ UNAMA commented that the weakness of both central and provincial administrations, and the disconnect between the two were a continuing constraint. ${ }^{165}$ The involvement of regional power holders in the current and future government of Afghanistan

\footnotetext{
${ }^{154}$ Security and Peace Support in Afghanistan: Analysis and Short to Medium Term Options, William J. Durch, The Henry Stimson Centre, August 2002

155 Ev 84

${ }_{157}^{156} \mathrm{Ev} 80$

${ }_{158}$ Meeting with Daoud Yaqub, Policy Co-ordinator, National Security Council, Kabul, October 2002

158 Securing Afghanistan: The Need for More International Action, International Crisis Group Asia Briefing Paper, 15 March 2002

${ }_{159}$ During our visit we were told that in Herat, the regional power holder Ismail Kahn, despite being known as a perpetrator of human rights abuses, maintained relatively effective local government and even had some welfare systems in place to protect the most vulnerable. Further details of regional power holder involvement in violent clashes and looting can be found in: 'The Afghan Transitional Administration: Prospects and Perils', International Crisis Group Afghanistan briefing paper, 30 July 2002

160 Meeting with European Commission Representatives, Kabul, October 2002

161 All Our Hopes are Crushed: Violence and Repression in Western Afghanistan, Human Rights Watch, 5 November 2002

162 'The Afghan Transitional Administration: Prospects and Perils', International Crisis Group Afghanistan briefing paper, 30 July 2002, Securing Afghanistan: The Need for More International Action, International Crisis Group Asia Briefing paper, 15 March 2002

163 'The Afghan Transitional Administration: Prospects and Perils', International Crisis Group Afghanistan briefing paper, 30 July 2002

164 Ev 80

${ }^{165}$ Ev 37
} 
will be discussed in more detail in paragraph 63 but evidence suggests that some "warlords" and other local commanders are amassing weapons, hampering agency programmes and in some areas are preventing the safe return of refugees and internally displaced peoples. ${ }^{166}$

\section{The International Security Assistance Force}

52. The International Security Assistance Force (ISAF) was established to "assist the Afghan Interim Authority in the maintenance of security in and around Kabul and its surrounding areas". ${ }^{167}$ The mission is comprised of an armed force of twenty-one nations led initially by the UK. After a period of Turkish leadership the Germans and Dutch took over in December 2002. ${ }^{168}$ With 5000 troops at its command it is only able to mount 35 to 40 patrols per day. ${ }^{169}$ On our visit we saw first hand the increased security that ISAF presence has brought to Kabul. Some semblance of normality has been resumed in the capital although its aura of calm is perhaps deceptive. ${ }^{170}$ Nevertheless, the ISAF presence has brought about a shift in dispute resolution from the use of force, to an acceptance of negotiation: its stabilising effect is perceptible. ${ }^{171}$ ISAF has worked hard at gaining acceptance in a country which is widely thought to resent automatically the presence of foreign troops. We were told by Col. Levey at Camp Souter, that ISAF had achieved good communications with the Transitional Administration and that its Psyops (Psychological Operations) and work with CIMIC (Civil and Military Co-operation) had helped to overcome local resentment and make ISAF acceptable - at least in Kabul. ${ }^{172}$ Unfortunately the remit of ISAF only extends to Kabul and immediate surrounding areas, the rest of the country still suffers insecurity. Christian Aid have stated: "The limited ISAF mandate has meant that the regional power holders have consolidated their power and many act autonomously outside Kabul". ${ }^{173}$

53. There have been calls from all quarters (including the Transitional Administration), with varying degrees of enthusiasm, for the expansion of ISAF. ${ }^{174} \mathrm{CARE}$ International told us, "most experts agree that the 4,500 member ISAF Force is a wholly inadequate response to the security situation in Afghanistan". ${ }^{175}$ It has been suggested that $25,000-30,000$ troops would be needed to provide security in Afghanistan's main cities. ${ }^{176}$ Expanding the remit of ISAF across the country may reduce the current jostling for power, increasing stability and reducing the prospect of neighbours (particularly Iran) interfering in local politics. ${ }^{177}$ Recent announcements have renewed ISAF's mandate for another year but have not extended its remit across the country. ${ }^{178}$ The USA, despite its concerns about interference from neighbouring countries in local Afghan politics, has been reluctant to expand ISAF's mandate and this has effectively prevented any movement on the subject. ${ }^{179}$ Tom Phillips, the UK Special Representative for Afghanistan, told the Committee that there was little prospect of expanding ISAF, a view echoed by the Secretary of State. ${ }^{180}$

\footnotetext{
${ }^{166}$ Ev 84

${ }^{167}$ UN Security Council Resolution 1386 (20 December 2001)

${ }^{168}$ Ev 80

169 Meeting with Col. Levey of ISAF, Camp Souter, Afghanistan, October 2002.

170 Securing Afghanistan: The Need for More International Action, International Crisis Group Asia Briefing Paper, 15 March 2002

171 Ibid.

172 Meeting with Col. Levey of ISAF, Camp Souter, Afghanistan, October 2002

${ }^{173} \mathrm{Ev} 84$

174 E.g.: Ev 52, Ev 133, Ev 80, Ev 84, Ev 121, Q3, Q127, QQ153/4, Q208

175 Ev 52

${ }^{176}$ Securing Afghanistan: The Need for More International Action, International Crisis Group Asia Briefing Paper, 15 March 2002

177 Ibid.

${ }_{178}$ HC Deb, 2 December 2002, col 59-60WS

${ }^{179}$ Securing Afghanistan: The Need for More International Action, International Crisis Group Asia Briefing Paper, 15 March 2002

${ }^{180} \mathrm{Q} 52$
} 
Alternatives to expanding ISAF, such as Joint Regional Teams, are being investigated and the need to expand the stabilising "ISAF effect" has been widely recognised. ${ }^{181}$ Reluctance to expand ISAF may be related to a lack of resources although the Policy Coordination of the National Security Council told us while we were in Afghanistan that a only small number of forces would be necessary to extend peace. ${ }^{182}$

54. The Secretary of State felt that it would have been highly desirable to have an ISAF presence in every major city to give a sense that security was spreading. But the USA had not been open to that view. ${ }^{183}$ The will for such an expansion no longer exists and Germany and the Netherlands, like Turkey before them, have only agreed to take over ISAF's leadership on the basis that there is no expansion of its mandate. With the momentum for ISAF's expansion gone, other ways will have to be found-one possibility being to place security teams in all the cities. Clare Short saw the idea of regional teams as a second best solution but, nevertheless, one worth setting up quickly. ${ }^{184}$ It would, she hoped, send the message: "security is coming outside Kabul. Listen, warlords. The international community is not going away. You might as well come inside the tent because you are not going to be able to play around like you did before." ${ }^{85}$ The idea of small regional multi-disciplinary teams has begun to materialise in the form of Joint Regional Teams (JRTs).

\section{Joint Regional Teams}

55. The United States has been working on an alternative plan to ISAF expansion, with some input from other countries, especially the UK. This involves the establishment of small multinational teams in eight regions across Afghanistan. These Joint Regional Teams (JRTs) are being established as part of the coalition forces' progression into Phase 4; that is moving into the reconstruction of Afghanistan. ${ }^{186}$ They would attempt to bring the influence of the Afghan Transitional Administration beyond Kabul, to deal with instability caused by regional power holders and to play a part in reconstruction and humanitarian projects. ${ }^{187}$ The teams will therefore include both military personnel and those expected to carry out civilian tasks. Establishment of JRTs, security sector reform and disarmament, demobilisation and reintegration (DDR) would be simultaneously embarked upon. The first American-led team established in Gardez has been deployed and a British-led Team is also under consideration. ${ }^{188}$ Further teams will be established once these are in place, building on experience. There have been complaints of a lack of consultation with Afghans, including the Transitional Administration, or the aid community and correspondingly there is little ownership of the idea. It is also likely that the teams will cut across established humanitarian and development aid programmes if they are set up in the way proposed. The possible role of JRTs in coordinating the development effort needs to be clarified, at present this is the responsibility of the UN under the terms of the Bonn agreement.

56. Aid agencies, NGOs and UN alike, are concerned that established principles of neutral assistance based on need and provided impartially, in line with the National Development Framework and with input from communities, may be compromised. The blurring of distinctions between the military and civilian operations may further endanger

\footnotetext{
181 Q51

182 Meeting with the Committee, Kabul, October 2002

${ }^{183} \mathrm{Q} 236$

184 Ibid.

185 Ibid.

${ }^{186} \mathrm{Q} 58$

187 A British Agencies Afghanistan Group briefing paper on the development of Joint Regional Teams in Afghanistan, Barbara J. Stapleton, January 2003

${ }_{188}$ US forces in Afghanistan to deploy new strategy over Christmas, Ahmed Rashid, The Nation, Lahore 30 December 2002
} 
the safety of aid workers, Afghan and non Afghan alike, and the trust that they have built up, by being seen as part of, or supporting, operations by a party to the conflict. The new forces arriving in Gardez have already been described as ISAF forces, illustrating the confusion that exists. If the JRTs are all that is on offer then Afghans may feel that they have no choice but to accept them. If they can enhance security then they are to be welcomed, but they are a second-best option to the expansion of ISAF. Our initial concern is that without a specific peacekeeping mandate JRTs will be able to do little to bring security to the population and may not enhance the aid effort either. We are also concerned about the lack of information about JRTs and recommend that the UK Government issue a statement detailing British involvement and setting out the mandate, range of duties and composition of existing and planned JRTs.

\section{Long-term security for Afghanistan}

57. Simply increasing the numbers of foreign peacekeepers in Afghanistan is not a satisfactory long-term solution to Afghanistan's security problems. Islamic Relief's Sakandar Ali even went so far as to call the security that ISAF had brought a "forced peace" and emphasised that development of a thriving economy was likely to be more important to stability in the long-term . ${ }^{189}$ The development of an Afghan national army, a police force, a cadre of border guards, the judiciary and criminal justice system will be vital to long-term security. But the impact of ISAF and the need for a continuing international presence should not be underestimated. One Afghan journalist commented that: "The best thing the world can do right now is to have an American B-52 fly overhead once a day. It doesn't need to drop anything; everyone just needs to see that the Americans are still here and paying attention". ${ }^{190}$ A war against Iraq is likely to result in the diversion of resources elsewhere.

\section{A National Army and Police Force}

58. It has been clear from the outset that an indigenous Afghan Security Force will be necessary to ensure the country's long-term stability. The international community have made helping the Afghans in this area a high priority. ${ }^{191}$ UNAMA's written evidence stated that "There will be no long-term solution to the security problems of Afghanistan unless and until a well trained, well equipped and regularly paid national police and national army are in place". ${ }^{192}$ Much of the evidence we received emphasised the length of time that would be needed to build a national army and police force. ${ }^{193}$ No money was pledged at Tokyo to deal specifically with police and security issues. Reports from DFID have suggested that progress so far on the creation of Afghan security forces and institutions has been slow. ${ }^{194}$ The Afghan Transitional Administration recently issued a decree setting down principles for the establishment of a 70,000 strong national army and the UN and the Japanese government are helping to prepare for a comprehensive programme of disarmament and reintegration. ${ }^{195}$ Christian Aid rightly emphasises that police and army projects: "will only be effective if there is sufficient international support (financial, technical and training)". ${ }^{196}$

\footnotetext{
${ }^{189} \mathrm{Q} 153$

190 Securing Afghanistan: The Need for More International Action, International Crisis Group Asia Briefing paper, 15 March 2002

${ }^{191}$ Bonn Agreement, December 52001 \& Securing Afghanistan: The Need for More International Action, International Crisis Group Asia Briefing Paper, 15 March 2002

${ }^{192} \operatorname{Ev} 37$

193 Ev 52, Ev 80

194 Ev 15, Ev 117

195 Decree on the Afghan National Army issued by the Islamic Transitional State of Afghanistan, 1 December 2002

${ }^{196}$ Ev 84
} 
59. Afghanistan's ethnic diversity presents a further challenge to the establishment of a police force and army. Afghanistan's ethnic groups have not always had an easy relationship with one another, and ethnic differences have featured recent prominently in local and national power struggles. The Taliban came from the largest ethnic group - the Pashtun. Since the Taliban's fall this ethnic group has been particularly vulnerable and has suffered persecution and attack. ${ }^{197}$ The ethnic balance of the Afghan Transitional Administration reflects changes in the power hierarchy of different groups and the Defence, Interior, and Foreign ministries of the Transitional Administration are all controlled by prominent ethnic Tajiks, the group from which most Northern Alliance members were drawn. In Kabul, EU Special Representative Francesc Vendrell emphasised the importance of making sure that the Pashtuns did not feel left out of the higher echelons of the predominantly Tajik army. ${ }^{198}$ Special emphasis will need to be placed on making the police and military genuinely integrated ethnic forces, not simply an extension of Northern Alliance power.

\section{An Afghan National Army}

60. The Secretary of State described the creation of a multi-ethnic National Army as a task that would take years. ${ }^{199}$ The main problem facing the Afghan National Army (ANA) is how to unify it. On the $1^{\text {st }}$ December 2002 the Afghan Transitional Administration issued a decree on the ANA which re-affirmed the commitment to ensuring that it will be staffed "inclusive of all social and ethnic groups". ${ }^{200}$ But the incorporation of different groups that have been fighting against each other in the recent past will not be an easy task. There is also a concern that the development of a national army will, in practice, provide warlords with access to better trained and equipped personal forces. Clare Short accepted that there was a risk but saw it as less of a gamble than keeping warlords "outside the tent" ${ }^{201}$ We see no clear alternative to the approach described by the Secretary of State as saying to the warlords: "Security is now coming outside Kabul, the international community is not going away, American power is not going away, the government will be strengthened, there will be a national army. "Come inside the tent or you are nowhere." 202 Any army has to be subordinate to the political administration. Defence Minister Mohammed Fahim is a case in point. Appointed at the Loya Jirga, Fahim has recently promoted himself to Marshal and has been choosing and appointing an array of sympathetic generals and commanders who have become involved in struggles with rival forces or militias. ${ }^{203}$ What currently exists as a national army is itself a faction and the ambitions of Fahim are a major cause for concern. Given the timescale involved, we believe that the creation of a national army should proceed in step with progress in building the democratic institutions and systems of accountability to the political administration to allow it to function as an army should.

\section{A Police Force}

61. Rising crime levels since the collapse of the Taliban have increased the need for policing which is acceptable in all communities. Before the Taliban, policing was carried out by a soviet-style quasi-military force. Under the Taliban the police force were replaced by the Ministry for the Promotion of Virtue and the Prevention of Vice. ${ }^{204}$ At the moment

\footnotetext{
197 Ibid.

198 Meeting with the Committee, Kabul, October 2002

199 Q243

${ }^{200}$ Op. cit

$201 \mathrm{Q} 243$

$202 \mathrm{Q} 243$

203 The Afghan Transitional Administration: Prospects and Perils', International Crisis Group Afghanistan briefing paper, 30 July 2002

${ }^{3}$ Securing Afghanistan: The Need for More International Action, International Crisis Group Asia Briefing Paper, 15 March 2002
} 
ISAF works closely with the existing police force, many of who returned to work after the fall of the Taliban. Germany has taken the lead in working on policing and has been assisted by the UK and Russia. ${ }^{205}$ UNAMA have reported good progress in this area but called for further donor funding. ${ }^{206}$ Widespread reform of the existing force and system will be necessary to create a police force understanding of the need for transparency, human rights training and anti-corruption efforts. The International Crisis Group have expressed concern that the Transitional Administration has given little thought to such reforms and has also emphasised the need for police monitoring, particularly in respect of financial accountability, given the poor record of police forces in other transitional societies. ${ }^{207} \mathbf{W e}$ are concerned that too great an emphasis may be placed on the creation of a national police force. This strikes us as one area where an incremental and sectoral approach may be more rewarding. A priority for central government is the protection of Afghanistan's porous borders and the securing of customs and other revenues. The establishment of a border protection force might confer considerable benefit in the medium term, as a precursor to the final establishment of a national service.

\section{Disarmament, demobilisation and reintegration}

62. In December 2002 the Afghan President signed a decree setting down the principles for the disarmament, demobilisation and reintegration (DDR) of former combatants into civilian life. ${ }^{208}$ Possession of arms is widespread right across Afghanistan. CARE International estimated that more than half a million Afghans carry arms. ${ }^{209}$ Many Taliban fighters who surrendered were allowed to return to their homes while keeping hold of their weapons. ${ }^{210}$ In the context of Afghanistan's historical and current insecurity, holding arms for personal protection is understandable, particularly in areas where law and order has collapsed and factional fighting has resumed. CARE International emphasised the traditional reliance on arms as a means to settle disputes and reported increasing banditry as a: "symptom of the high level of ownership of arms in a poor country". ${ }^{211}$

63. Despite the identification of such problems DFID has reported that "there is a lack of a clear agency lead in Disarmament, Demobilisation and Reintegration activities" on which UNDP is taking the lead with Japanese government funding. ${ }^{212}$ It has also reported a similar lack of lead in activities to promote alternative livelihoods as an incentive to draw people away from soldiering. ${ }^{213}$ DFID is providing consultancy advice through UNAMA to devise the programme and methods for verifying that disarmament has taken place. ${ }^{214}$ Such programmes are crucial to achieving disarmament; militia fighters and those involved in crime are involved partly because of the lack of alternative means to survive or provide for themselves and their families. DDR is dependent on economic development which in turn is dependent on stability and security. As Sakandar Ali of Islamic Relief told us: "real security will only come when there is the infrastructure, when there is a thriving economy and people have jobs to do and therefore we would demobilise soldiers. That then will become a very conducive environment for future investment and long-term investment.". ${ }^{215}$ The UK has recent experience of DDR in Sierra Leone. We hope that DFID will also play a major part in driving forward a DDR programme and that it emphasises the

\footnotetext{
205 The Afghan Transitional Administration: Prospects and Perils', International Crisis Group Afghanistan briefing paper, 30 July 2002

206 Ev 37

207 Securing Afghanistan: The Need for More International Action, International Crisis Group Asia Briefing Paper, 15 March 2002

${ }^{208}$ Ev 117

209 Ev 52

210 Meeting with EU Special Representative, Kabul, October 2002

$211 \mathrm{Q} 127$

212 Ev 15, Q244

${ }^{213}$ Ev 16

214 Ev 117

${ }^{215}$ Q153
} 
importance of this issue to other donors along with the need to give financial settlements to former fighters. We are conscious, however, that no DDR programme will succeed unless it is underpinned by the employment opportunities that will come with economic development.

\section{A Strategy for dealing with warlords}

64. The reluctance amongst regional power holders to return regional tax and customs revenues to central government has left a significant gap in the Afghan Transitional Administration's budget. ${ }^{216}$ In Kandahar alone US $\$ 18$ million is collected every year by the local "warlord" and in Herat the estimated figure is US\$50 million per annum. ${ }^{217}$ The Transitional Administration needs therefore to bring revenue collection under its control. Regional leaders' lack of any loyalty to the Transitional Administration raises concerns as to whether a national police and military would be accepted by regional political and military forces. ${ }^{218}$ Although the policy of incorporating regional power holders into the Transitional Administration has enabled a degree of regional governance it may lead to problems in controlling them or declaring them outside of that authority later on. ${ }^{219}$ The Transitional Administration has tried both to incorporate regional power holders, and to diminish their regional power. But whilst the Transitional Government can use the blocks on funding or the threat of force to try to bring regional leaders under control, it has to be careful not to isolate them. The Transitional Administration's legitimacy could disintegrate if large parts of the country rejected its authority. ${ }^{220}$ Although regional power holders have not been prosecuted for human rights abuses perpetrated before the Loya Jirga, many of their foot soldiers have been imprisoned. This approach could breed resentment amongst the local population and hence further insecurity.

65. The policy of working with warlords is not confined to the Transitional Administration. Human Rights Watch has criticised international actors for legitimising and supporting regional power holders who continue to perpetrate human rights abuses. It has highlighted Ismail Khan, local Governor of Herat, who has been consistently supported by the US and Iranian governments. ${ }^{221}$ When asked about the strategy of incorporating warlords, Tom Phillips cited Mohammed Fahim as a reformed warlord now playing a constructive role in the Transitional Administration. ${ }^{222}$ But we have heard that the military ambitions of Mr Fahim and his role in the development of the national army remain a cause of concern. Christian Aid notes: "regional power holders are unlikely to simply surrender the power they have fought for" and ways must be found to encourage power holders to take a stake in peace and long-term stability. ${ }^{223}$ Recent developments indicate that the Afghan Transitional Administration is revising its strategy for dealing with rogue regional power holders: decrees have been issued forbidding them from having both political and military roles in the provinces and ordering that their armies must be disarmed and demobilised by June $2003 .^{224}$ We welcome this new approach to dealing with the "warlord" problem. Policy towards regional power holders needs to be reviewed continually in the light of what we hope will be the Afghan Transitional Administration's growing legitimacy and eventual control over revenue collection. We believe the funding of "warlords" by the internationally community to be a short-

\footnotetext{
${ }^{216} \mathrm{Ev} 80$

${ }_{217}$ Karzai takes on the warlords, Ahmad Rashid, The Nation, Lahore, 30 December 2002.

218 Securing Afghanistan: The need for More International Action, International Crisis Group Asia Briefing Paper, 15 March 2002

219 The Afghan Transitional Administration: Prospects and Perils', International Crisis Group Afghanistan briefing paper, 30 July 2002

220 Ibid.

221 All Our Hopes Are Crushed: Violence and Repression in Western Afghanistan, Human Rights Watch, November 5 2002 .

222 Tom Phillips is UK Special Representative for Afghanistan

223 Ev 84

${ }^{224}$ Karzai takes on the warlords, Ahmad Rashid, The Nation, Lahore, 30 December 2002.
} 
sighted approach to the fight against terrorism which undermines the long-term objective of achieving stability and security within the country and across the region. We are concerned about reports of human rights abuses against prisoners and note the comments made by the International Committee of the Red Cross, calling for prisoners to have their legal status determined on an individual basis. ${ }^{225}$ There is also, we consider, a lack of equity in the policy under which a line has been drawn under warlords' past crimes, while those acting under their authority have been imprisoned. We recommend an examination of the situation of such prisoners and their release where possible.

\section{The Judiciary and criminal justice system}

66. A level of basic regional administration continued throughout Afghanistan's war years. Unfortunately the same cannot be said for the judicial system. Italy is leading on the development of the judiciary and the UK is considering seconding a judicial adviser and making a contribution to the International Trust Fund established to take forward the work on this sector. ${ }^{226}$ The problem seems not to be a lack of law, but a lack of clarity over which laws are enforceable, and a lack of any mechanism through which to enforce them. Not only does Afghanistan lack lawyers and judges trained in its mixture of Islamic and civil law, but even its few experts are uncertain which laws are actually in force.227 Tom Phillips set out the formal legal position saying that: "at the moment ... the 1964 constitution holds, then secular law, then Sharia". ${ }^{228}$ A Judicial Commission has now been appointed by the Transitional Administration and hopes are high that it will meet the massive task ahead of it: to consolidate Afghanistan's law into an accessible format and to establish programmes for the training of lawyers and judges and the rebuilding of courts. ${ }^{229}$ The Commission will need to address the whole spectrum of the criminal justice system from arrest to trial and eventual punishment on conviction. At present there is no clear indication of where suitable people to appoint as judges, lawyers or police officers will be found. Such practical concerns underpin the whole security issue and the successful operation of a fully-functioning criminal justice system.

\section{A regional approach}

67. Some commentators favour a regional approach, focussing on how the stability and security of neighbouring countries is linked to the situation in Afghanistan. ${ }^{230}$ Many of the Taliban spent time in exile in Pakistan, often working in madrassas and many fled back there following the collapse of the regime. Many Taliban crossed the border into Pakistan's North West Frontier Province and Balochistan, regions where Islamist parties were successful in Pakistan's recent elections. ${ }^{231}$ In her evidence, Clare Short stressed the need for long-term, sustained engagement with Pakistan, India and the Central Asian republics, as well as with Afghanistan. ${ }^{232}$ Taking a regional approach entails not only understanding how conflict in Afghanistan has affected it neighbours, but also how postconflict reconstruction can bring opportunities for regional development. Despite past interference from Afghanistan's neighbours the Foreign and Commonwealth Office is confident that Afghanistan will not be a focus for regional rivalries. We welcome the

\footnotetext{
225 Ev 146

${ }^{226}$ Q75, Ev 117

227 The Afghan Transitional Administration: Prospects and Perils', International Crisis Group Afghanistan briefing paper, 30 July 2002

$228 \mathrm{Q} 76$

${ }^{229}$ Q7, The Afghan Transitional Administration: Prospects and Perils', International Crisis Group Afghanistan briefing paper, 30 July 2002 \& Bonn Agreement, December 2001

230 Afghanistan's reconstruction, regional and country context, a discussion paper, William Byrd, Revised Draft, October

31,2002

$231 \mathrm{Q} 233$

232 Ibid.
} 
signing on the 22 December 2002 of a regional non-interference declaration by Afghanistan's closest neighbours, although we are concerned about the absence of Russia, India and Saudi Arabia as key signatories. ${ }^{233}$ US Secretary of State Colin Powell said in a speech to the World Bank in September 2002: "One year ago Afghanistan was an exporter of instability in the region. Today it seeks to be a contributor to regional wellbeing". ${ }^{234}$ Extending beyond security, a regional approach should have economic policy implications which might include opening trade across the region and developing crosscountry infrastructures to help the development of the Afghan and regional economy We recommend that DFID and other donors, together with the UNDP, carry out an assessment of how opening up regional trade might help the Afghan economy, benefit long-term reconstruction and provide alternative livelihoods for militiamen and poppy farmers.

\section{CONTINUING HUMANITARIAN NEEDS-FOOD AID AND FOOD DEPENDENCY}

68. At least 60 per cent of the money pledged to Afghanistan has been spent on humanitarian relief, much of it in the form of food aid. The USA, the single largest funder has provided 38 per cent of its total disbursement as food. ${ }^{235}$ India has also provided a large percentage of its contribution in kind rather than in cash. The most immediate need is for targeted short-term food aid for the estimated 5.8 million vulnerable people. ${ }^{236}$ There have been major improvements since our last report when the WFP's Regional Emergency Operation was targeting seven and a half million beneficiaries. ${ }^{237}$ UNAMA estimates that the numbers needing food aid in 2003 will be 4.1 million. ${ }^{238}$ Evidence suggests that the agricultural harvests in 2002 have improved by as much as 80 per cent ${ }^{239}$ Unfortunately this improvement has been uneven across Afghanistan and some areas have only seen increases of 30 per cent. ${ }^{240}$ The situation is compounded by the return of refugees, which has occurred at a faster rate than expected. ${ }^{241}$ The onset of winter has further increased the vulnerability of many Afghans as their needs for adequate shelter become more pressing. Winter has also brought with it access problems as communities are cut off and isolated for the outside world by extreme weather conditions. Programmes are in place providing temporary shelters, tents and blankets and the UN is providing 115 snowploughs to help address access problems. ${ }^{242}$ Christian Aid was amongst those who told us that the WFP is experiencing funding shortfalls and this could be preventing some Afghans from getting much needed assistance with food and shelter. ${ }^{243}$ Oxfam stated that "In the central highlands the WFP has been slow in delivering food to Oxfam as a result of funding shortages". 244

69. Humanitarian assistance in the form of food aid and the provision of temporary shelters remains vital in helping Afghans with basic survival needs. But humanitarian relief must begin to focus on the longer-term. A strategy is needed for how Afghanistan is to move from keeping people alive to providing them with livelihoods. Clare Short told

\footnotetext{
233 A Desire to be Left Alone: Afghanistan's power-hungry neighbours threaten to revive the ruinous civil war of the early 1990s that gave rise to the Taliban, Ahmed Rashid, Far Eastern Economic Review, January 22003.

23426 September 2002, cited in Ev122

235 Ev 68

${ }^{236}$ World Food Programme Vulnerability Assessment Mission, October 2002, cited in Ev 84

237 International Development Committee, First Report, 2001-02, The Humanitarian Crisis in Afghanistan and the Surrounding Region (HC300-I)

${ }^{238}$ Ev 37

239 Ev 84, Ev 37

${ }^{240}$ Ev 84

${ }^{241}$ Ev 80, Ev 84, Ev 37

242 Ev 37

243 Ev 84

${ }^{244}$ Ev 121
} 
us that "you cannot turn away from the humanitarian needs while you are trying to build up the structures". ${ }^{245}$ We agree, but would also say that you cannot ignore the need to build structures and institutions if you are ever to move beyond providing humanitarian relief. Christian Aid has stressed the importance of "provision of seeds, livestock and other inputs for spring planting, to help guarantee that next year's harvest is adequate for the provision of food to the region". ${ }^{246}$ The provision of food aid is hampering the development of local agricultural recovery and may in some cases be creating dependency. ${ }^{247}$ Afghanistan's Finance Minister was especially concerned about the impact that food aid in kind had on food prices and on cultivation. ${ }^{248}$ The provision and stockpiling of wheat has the potential to have a direct, negative impact of the sale of wheat by local farmers. As Christian Aid noted: "local markets can be suppressed where local people are accessing free wheat distributions. Doling out of free food in this way is short sighted". ${ }^{249}$ If the price that local farmers can get for their wheat is reduced, there is less incentive for them to grow wheat and more incentive for them to grow poppies which provide very high cash returns. Christian Aid's Roger Riddell told us that: "the local price of wheat has fallen from about 20 new Afghanis to about 4 new Afghanis, about 30 cents a kg" and that 20 to 40 times this amount can be reaped from opium production. ${ }^{250}$

70. A lack of cash in the Afghan economy is leading to "increased vulnerability of the landless and of small landowners who are dependent on seasonal casual labour to cover basic family needs such as food, clothing and medicines". 251 Injecting more cash into the economy should aid its development at both local and national level. And in doing so, have a positive impact on Afghanistan's long-term stability and future dependence on food aid. The Transitional Administration has been critical of programmes such as those run by the WFP in the Shomali Valley which distribute food to Afghans in return for work. Food for work programmes address the issue of availability of food. But often the food is available, the problem is that people do not have the money to buy it. In light of the desperate need for cash in the economy, a system of giving cash for work would be more likely to stimulate local economies. The Afghan Minister for Rural Development and Reconstruction told us: "Our preferred instrument is cash for work. Food aid will not address the causes of the poverty of our people. Therefore we should like to engage constructively with the donors and explore reconstruction aid to strengthen the cash-starved economy of our country". ${ }^{252}$ Afghanistan is the victim of a chronic rather than an acute food shortage. Food aid in Afghanistan is now the wrong response, as it is in other parts of the world where it has also failed to address food shortages. What is needed is an improvement in food security. DFID took a different view, arguing that as access to food continued to be a problem for many communities, it was not practical to offer solely cash for work. ${ }^{253}$ There are still vulnerable communities inside Afghanistan but, by and large, we endorse a move from food to cash for work. We understand the difficulties of such a transition in an fragile economy but the response has to be to build the economy rather than persist in policies which undermine food production.

\footnotetext{
${ }^{245} \mathrm{Q} 209$

${ }_{246}^{242}$ Ev 84

247 Ibid.

${ }^{248} \mathrm{Ql}$

${ }^{249}$ Ev 84

${ }^{250}$ QQ1 $84 / 5$

251 Ev 144

252 Q15

${ }^{253}$ Ev 117
} 


\section{DRUGS}

71. The Prime Minister has spoken of the need to eradicate the opium poppy harvest as part of the programme of action in support of coalition action against Afghanistan. ${ }^{254}$ The UK has since taken a lead in developing a UN eradication programme. Last year the Afghan government estimated that about 25 per cent of the crop was eradicated in the eradication programme, a fairly substantial success. The amount of heroin destroyed was $£ 5$ billion at UK street prices, so it made quite a significant impact. ${ }^{255}$ But the success of the eradication programme was soured when, in Kabul, Ashraf Ghani complained that the donor community had failed to honour what he saw as its side of the bargain by providing support for alternative livelihoods as a compensation package. He described it as the single issue which had lost him most credibility within the government and in the regions affected.

72. Despite the early successes in destroying poppy fields and the ban on opium poppy cultivation, new UN figures show that the eradication programme has had unforseen consequences. The UN crop survey, published in November 2002, showed that Afghanistan is set to resume its place as the source of 75 per cent of the world's and 90 per cent of the UK's heroin supply. ${ }^{256}$ The UN estimate that 3,400 tonnes of opium will be produced in Afghanistan in 2002 is much higher than the estimated 185 tonnes produced in 2001, following a Taliban ban on poppy cultivation. Although this recent rise amounts to a twenty-fold increase in opium production, production had dramatically increased under the Taliban and it was only in the final year of the regime that poppy growing was banned. The ban had a limited effect since the regime did little to destroy stocks and laboratory facilities. Money was still being made but higher up the production chain. ${ }^{257}$

73. The reasons for this rise in production are varied but they include the increased incentive to grow poppies resulting from the higher price which the crop commanded due to shortages caused by the eradication policy. In addition, some farmers may well have grown poppies in the hope of receiving the compensation that was paid out to those whose crops were eradicated. High levels of debt pose a serious threat to the recovery of local communities. ${ }^{258}$ When farmers grow opium, they borrow money from the traders. A lot of farmers found themselves significantly in debt because of the opium ban imposed by the Taliban and have needed to cultivate poppies again this year in order to repay.

74. None of the alternatives to poppy cultivation can compete with its profitability. ${ }^{259}$ So the alternative crops approach of trying to persuade farmers to change what they grow is unlikely to win easy converts. Even DFID's Chris Austin said that: "I do not think experience elsewhere has shown that crop substitution is really going to work in Afghanistan" ${ }^{260}$ Current policies aim to persuade farmers to move over to other high-value crops such as saffron and cumin, but an export market is necessary for these crops to be successful. This is perhaps less daunting than it may appear-at one time Afghanistan supplied forty per cent of the world's raisin market. But even so, other high-value crops have disadvantages compared with the poppy, which grows in very poor conditions and brings in large amounts of money. This policy may be more effective in areas where farmers have only recently started to grow poppy but if persuading Afghan farmers to grow alternative crops is not an effective policy, encouraging them towards alternative livelihoods may be more successful. Poppy cultivation is labour intensive and relies on the

\footnotetext{
254 'UK heroin fight hit by record opium harvest', The Guardian, 26/10.02. See also Prime Minister's Speech to the Labour Party Conference, 3 October 2001

${ }_{255}^{2571}$

256 'UK heroin fight hit by record opium harvest', The Guardian, 26/10.02

257 Q71

258 Ev 144

259 Q204

${ }^{260} \mathrm{Q} 72$
} 
availability of cheap labour. If more Afghans were employed in construction work on road building and other infrastructure projects, this may reduce the supply of labour and the tendency to turn to poppy cultivation. ${ }^{261}$ Peter Marsden of the British Agencies Afghanistan Group said: "I do not think it is realistic to look at alternative crops as a way forward. The only way forward is alternative livelihoods, perhaps through the urban economy". ${ }^{262}$

75. The UK has set a target of 70 per cent reduction of opium poppy crops by 2008 and 100 per cent elimination by $2013 .{ }^{263}$ This is an ambitious goal and, as Tom Phillips recognised, success will depend on building up law enforcement capability and institution building. ${ }^{264}$ This in turn will depend upon development of an effective judicial system. In our view the law enforcement approach may be best targeted on the traders who source their supplies from farmers, rather than on the farmers themselves. Tom Phillips cautioned against expecting immediate results, believing that reconstruction had not yet reached a level where one could be confident that there were sufficient alternative livelihoods available to a significant number of Afghan farmers. ${ }^{265}$ Viewed on the basis of financial returns it is hard to see how progress with alternatives can be made. But there are other approaches. The gradual build-up of a law enforcement and judicial system will, we hope, marginalise the illegal activity of poppy production. There will then be a chance to offer farmers something which, while not as lucrative as poppy growing, will nevertheless have tangible benefits. The Secretary of State told us that although poppy farmers could not realistically be tempted away from poppy cultivation with the promise of equally valuable crops, they could and should be offered the alternative of "a better life that is a legitimate life" which would also allow them to reap the benefits of stability and provision of public services such as education for their children. ${ }^{266}$ We commend this approach. Of course, none of this deflects from the UK's responsibility to address its own demand for the drug. As Clare Short pointed out, "if we get Afghanistan to the point where there is no drug production, it will come to the UK from somewhere else."267

\section{GENDER}

76. Many pressure groups and NGOs have argued that Afghan women must be given equality but academic perspectives suggest that an approach that addresses women's needs whilst accepting a degree of difference between the sexes may be more helpful. ${ }^{268}$ This does not diminish the manifest strengths and abilities of Afghan women nor the importance of equality issues such as those centring around education or political participation and representation. Afghan society remains predominantly rural and conservative with strong traditions relating to the survival of an extended family. ${ }^{269}$ During the last 23 years of civil war and unrest Afghan women suffered poverty and violence and, under the Taliban's discriminatory policies, a ban on education and work. But the situation of Afghan women is also connected to their lives in a mountainous, resource-poor and patriarchal country. Policies on gender in Afghanistan have therefore to be carried out with sensitivity to the cultural context and aid work must not be perceived as 'foreign', 'un-Afghan', or 'un-

\footnotetext{
${ }^{261} \mathrm{Q} 202$

262 Ibid.

263 Q71

264 Ibid.

265 Ibid.

${ }^{266} \mathrm{Q} 248$

267 Ibid.

${ }^{268}$ Ev 133, Report of visit to Kabul (7-14 September 2002), Joan Ruddock MP (UK women's link with Afghan women), Strategic Coordination in Afghanistan, Nicholas Stockton, Afghan Research and Evaluation Unit, August 2002.

${ }^{269}$ Report of the Rapid Reaction Mechanism Assessment Mission: Afghanistan, gender guidelines, Sippi AzarbaijaniMoghaddam, European Commission Conflict Prevention and Crisis Management Unit, April 2002
} 
Islamic' and where these have been observed tangible achievements have been made. ${ }^{270}$ This is not to deny the enormous amount of work to be done. Work on the constitution and legal reform will be fundamental to ensuring women's rights. ${ }^{271}$ But the fear of a backlash means that the pace of change has to be right. DFID has recently voiced concerns about the establishment of a Department of Accountability and Religious Affairs in the Haj Ministry as its reported agenda echoes that of the Taliban Ministry for Vice and Virtue. ${ }^{272}$ BAAG's Peter Marsden gave a timely reminder of the dangers of moving too fast for traditional society: "There are significant threats, for example to efforts of families who send their children to school, and many schools have been burnt down and threatening letters sent and so on. History tells us that we should be made aware of the risk of a backlash in Afghanistan if the reform process moves too quickly". ${ }^{273}$

77. The Afghan Transitional Administration has a Ministry of Women's Affairs (MoWA) to take the lead on Women's issues. Womankind have told us in written evidence that MoWA is lacking in resources to establish itself and lacks expertise and a clearly defined role. ${ }^{274}$ The importance of mainstreaming gender as a consideration across government has been raised by a number of our witnesses and in published reports and should be a key priority for the MoWA. ${ }^{275}$ DFID have reported that there are plans for a national gender strategy and this could assist in development of an integrated approach spanning health, education, and employment. ${ }^{276}$ Commentators have also highlighted the importance of a greater female presence and involvement in public and political life and throughout society so that women are involved in decision making at all levels. ${ }^{277}$ In October 2002 the UN adopted Resolution 1325 urging the Secretary General to expand the role of women in UN field-based operations but there are no women running major agencies within Afghanistan and the top five UN posts in Afghanistan have been filled by men. ${ }^{278}$ We were concerned following press reports of the victimisation of women within the Transitional Administration and emphasise that vigilance is needed and positive initiatives must be fully supported.

78. Womankind highlighted a lack of data about the gender impact of donor funding and called for DFID to report on the breakdown of its contributions to donor programmes and their impact on the rights of women and girls. ${ }^{279}$ There has also been talk of a need for "gender auditing". ${ }^{280}$ This may involve a review of current projects targeting women's needs as well as an audit of women in high-level public positions. The Afghanistan Research and Evaluation Unit have called for: "A strategic gender policy review conducted jointly by the ATA, AACA and UNAMA with donor, IFI and NGO participation". ${ }^{281}$ As always, care must be taken to ensure that the costs of coordination and review do not outweigh the benefits but in this case a gender audit could help to get mainstreaming off the ground. DFID has a good track record in its commitment to gender issues and could act as an advocate for a thorough gender main-streaming approach within all

\footnotetext{
270 Ibid.

${ }^{271}$ For example imprisonment of women for minor offences has been raised as an issue requiring attention. Report of visit to Kabul (7-14 September 2002), Joan Ruddock MP (UK women's link with Afghan women)

272 Ev 117

273 Q194

274 Ev 133

${ }^{275}$ Ev 133, Q142, Q193, Report of the Rapid Reaction Mechanism Assessment Mission: Afghanistan, gender guidelines, Sippi Azarbaijani-Moghaddam, European Commission Conflict Prevention and Crisis Management Unit, April 2002, Strategic Co-ordination In Afghanistan, Nicholas Stockton, Afghanistan Evaluation and Research Unit, August 2002 ${ }^{276}$ Ev 15 , Ev 117

${ }^{277}$ Ev 58, Ev 133, Report of the Rapid Reaction Mechanism Assessment Mission: Afghanistan, gender guidelines, Sippi Azarbaijani-Moghaddam, European Commission Conflict Prevention and Crisis Management Unit, April 2002

${ }^{278} \mathrm{Q} 193$

279 Ev 133

$280 \mathrm{Q} 194$

281 Strategic Co-ordination In Afghanistan, Nicholas Stockton, Afghanistan Evaluation and Research Unit, August 2002
} 
donor activities and in political dialogue with the government. ${ }^{282}$ DFID should ensure that funding is provided for a gender audit.

79. The burkha is generally seen in the West as the symbol of all that is wrong with traditional Afghan attitudes to women. There has been disproportionate media attention given to whether women have stopped wearing their burkhas since the fall of the Taliban. But gender issues in Afghanistan are about more than whether women wear burkhas and are connected to deep-rooted traditions and broader societal problems. Women's family relationships should not be overlooked. On a previous visit to Afghan refugee camps inside Pakistan, burkha-wearing women told us of their primary concerns which were about their husbands being forcibly conscripted by the Taliban and of the lack of education for their children. In the long term, education will be the best strategy for addressing gender issues. Elizabeth Winter, special adviser to BAAG, recounted conversations with Afghan women who had told her that the solution lay in education for all. If Afghan women were educated they would be able find their own solutions to gender issues. ${ }^{283}$ These comments echo those of Afghan women who have said "Stop going on about the burkha. That is the least of our problems. Give us peace and we will then fight for our rights". ${ }^{284}$ We believe that education to secondary level, for both boys and girls, must be a priority and, in the long-term, will be the best method of addressing gender issues.

\section{REFUGEES AND INTERNALLY DISPLACED PEOPLE}

80. Most reports have indicated that refugees and internally displaced peoples are returning to their homes faster than predicted by the international community. ${ }^{285}$ UNHCR have taken this as an indication of the confidence of returning Afghans in the future stability of their country. But there are also "push and pull" factors influencing refugees' decisions ${ }^{286}$ Despite some seasonal dependence on migratory labour, Iran has operated a policy of encouraging refugees to return home. Life has been made more difficult for Afghans inside Iran as schools become closed to them, fines have been imposed on those employing Afghans and daily TV broadcasts advertise to Afghans that the UN is waiting to help them return home. ${ }^{287}$ Unfortunately many have found the return journey more difficult that the enticements suggest. Peter Marsden, speaking about the situation in Iran told us: "the radio and TV broadcasts have had a standard item each day saying 'Can we remind Afghans that now is the time to go home, that the UN will provide you with free transport to your home area and the UN will be there to assist you on your return' but when people arrive in Herat and find that there is only a contribution towards their transport costs clearly there is a lot of upset. I saw this myself on many occasions. Clearly when people return to the Shomali valley and find that only some people are getting assistance they are equally aggrieved". ${ }^{288}$ DFID has stated that there is no firm evidence of people being forcibly returned to Afghanistan from neighbouring countries, but the evidence we heard seems to indicate that host countries are putting pressure on refugees to leave. ${ }^{289}$

81. The returning refugees are increasing pressure on humanitarian relief resources and in some cases the aid community has not been able to assist everyone returning. The Committee visited the Shomali Valley where about a third of the refugees could not be assisted because of a shortage of resources. This may have led, in some cases, to refugees returning back again to the countries where they had sought asylum, although some

\footnotetext{
${ }^{282}$ Ev 133

${ }^{283} \mathrm{Q} 194$

${ }^{284} \mathrm{Q} 193$

285 Ev 80,

${ }^{286}$ Ev 130, Ev 15

${ }^{287} \mathrm{Q} 206$

$288 \mathrm{Q} 206$

289 Ev 117
} 
movement may be explained by dependence on migratory labour. DFID pointed out that not all people crossing Afghanistan's borders are refugees and notes that many Afghans regularly travel to neighbouring countries to work. ${ }^{290}$ In some cases families have returned, claiming benefits for doing so, and have then returned to the countries where they sought asylum, perhaps leaving one family member in Afghanistan to start farming work. ${ }^{291}$ With large numbers of people returning to ruined homes, existing communities can find themselves swamped and refugees are likely to drift to the cities in search of work. Afghanistan needs skilled people in almost every sector. Many highly-skilled Afghans are now returning and their skills should be used to best effect. ${ }^{292}$ The International Organisation for Migration has made progress in the area and some returning Afghans are already working for the Transitional Administration, donor and aid agencies. ${ }^{293}$ UNHCR considers that many returnees bring with them assets, capital and skills that will contribute to national recovery. But under present humanitarian conditions, their reintegration represents a sharp social and economic challenge if it is to be made sustainable. ${ }^{294}$ What is essential is that the Afghan Transitional Administration has a sustainable refugee return programme. Neighbouring states will have to be helped as well if forced or unsustainable repatriation is to be avoided.

\section{HUMAN RIGHTS}

82. Human rights remain a key issue in Afghanistan, particularly in relation to ethnicity and gender. Recent reports from UNAMA and Human Rights Watch (HRW) indicate that abuses are still widespread, particularly in Sharestan, Daikundi and Herat ${ }^{295}$ Human rights abuses inside Afghan prisons have also been reported, especially against those who were associated with the Taliban regime. We have expressed our concern earlier about imprisonment and punishment of the militia men of regional power holders while the power holders themselves have escaped prosecution, and have recommended that this is seriously investigated. In October 2002 a UN Special Envoy with a mandate from the UN Commission on Human Rights, visited mass graves and has recommended an international inquiry on human rights abuses in Afghanistan. She noted that mass killings which had occurred before, and throughout the Taliban's rule had not entirely ceased with the regime's demise. Although there had been a dramatic decrease in the number of killings, the continuing power of the gun meant there was a prevailing atmosphere of fear, especially outside Kabul. ${ }^{296}$ Changing this culture of conflict is the only way to ensure better protection of human rights and this will necessarily entail the integration of human rights into not only the constitution, law and policy but also into the framework of all institutions including the police and military. Human rights abuses perpetrated in the past by those regional power holders since incorporated into the Transitional Administration have been ignored by both the Transitional Administration and the international community. This has been a policy necessary to ensure workable government. ${ }^{297}$ The task now is to create a constitution, build institutions and a structure of accountability within which these regional power holders have to operate. We hope that the Human Rights Commission will be a vehicle for this.

\footnotetext{
290 Ibid.

291 Q206

292 Ev 80

293 Q55

294 Ev 130

295 Afghanistan Monthly Review, British Agencies Afghanistan Group, October 2002, All Our Hopes Are Crushed: Violence and Repression in Western Afghanistan, Human Rights Watch, November 52002

296 Afghanistan Monthly Review, British Agencies Afghanistan Group, October 2002

297 For details of the incorporation of regional power holders see: The Afghan Transitional Administration: Prospects and Perils', International Crisis Group Afghanistan briefing paper, 30 July 2002, Q61, Afghanistan: Torture and Political Repression in Herat: U.S. and U.N warlord strategy fails Afghan people, Human Rights Watch Press Release, November 5, 2002.
} 
83. At the Loya Jirga, President Karzai announced the creation of Commissions to address key issues facing the Transitional Administration. Four were given a mandate in the Bonn accord including a Human Rights Commission which was given a remit to educate, investigate and potentially adjudicate a variety of human rights questions. ${ }^{298}$ Others have been established since. The Commissions are intended as a means to involve Afghanistan's best and brightest in re-thinking and resolving the country's problems but it is unclear what their role and remit is and how they relate to their counterpart ministries. ${ }^{299}$ A recent AREU report raised the question of the independence of the human rights commission, rightly pointing out that the spirit of the Bonn Agreement was that it would be independent. ${ }^{300}$ If the human rights commission is government-led its independence will be compromised and as such its composition should be reconsidered. The following questions still have to answered: What relationship does it have with the courts and with the Ministry of Justice? Will the Commission be resourced to carry out its full mandate of monitoring, investigating, and educating? How will the Human Rights Commission deal with the issue of accountability for past crimes? How might the Commission act as a deterrent to future human rights abuses?

\section{PRIVATE SECTOR DEVELOPMENT}

84. The Secretary of State rightly emphasised the importance of an enabling environment: "the right enabling environment allows the domestic private sector to grow and makes the country more attractive to inward investment". ${ }^{301}$ Ashraf Ghani took the same view and had set his Finance Ministry to work on carrying out a value chain analysis and promoting business linkages. Private sector development is at a very early stage; during the visit some of our informal discussions left us with the impression that local business had not advanced beyond plans to import shampoo for aid workers and export Afghan carpets. The Finance Minister suggested a "made by Afghan women" label as a marketing tool which could stimulate the private sector through capitalising on Afghanistan's handicrafts and textile industries and current tariff free access to the EU. ${ }^{302}$ There is significant potential for development of the sector, for example through a revival of what was once a buoyant agricultural and horticultural industry. Other sectors with longer-term potential for development include assembly, tourism and mining. ${ }^{303}$

85. The lack of banking infrastructure in Afghanistan has forced aid workers to use the Hwala system or resort to carrying around suitcases of cash, not an ideal arrangement at the best of times but one that is particularly hair-raising in the context of Afghanistan's lack of security. ${ }^{304}$ It is hard to imagine private sector development getting very far in such circumstances. It was encouraging therefore to hear that banking was one of Ashraf Ghani's top priorities. DFID's Anne Freckleton, based in Kabul, also stressed the importance of developing both the judicial system and a regulatory framework for business. These, along with the rule of law and the securing of basic property rights will be fundamental to encouraging domestic and foreign investment. As always, sound economic management is the bedrock of an enabling environment and the Transitional Administration has taken its first step towards improving fiscal control by replacing the old currency. In the past, warlords have been able to print money but the new currency should allow the money supply to be controlled for the first time. In the long term, private sector

\footnotetext{
${ }^{298}$ The Afghan Transitional Administration: Prospects and Perils', International Crisis Group Afghanistan briefing paper, 30 July 2002

${ }_{300}$ Ibid.

300 Strategic Coordination in Afghanistan, Nicholas Stockton, Afghanistan Evaluation and Research Unit, August 2002.

$301 \mathrm{Q} 247$

302 Meeting with the Committee, Kabul, October 2002

303 Afghanistan's reconstruction: regional and country context, William Byrd, October 2002.

304 Hwala is a traditional Islamic, informal banking system where money can be paid in Pakistan and re-emerge in Afghanistan. Q247
} 
stimulation is likely to be the best strategy for tackling poverty in Afghanistan. Regional trade will also be important in allowing Afghanistan's economy to develop and a recent paper for the World Bank emphasises the likely benefits of developing a regional trade infrastructure and of opening up trade across the region. ${ }^{305}$

\section{CONCLUSION}

86. The hope, expressed in our previous report, that the Afghan people would be central to the development of their country has turned out to be overly optimistic. Afghanistan is a completely wrecked land with no institutions which work, no legitimate economy, no order or security, and serious capacity shortfalls within government. Reconstruction has had to begin from scratch in the face of a humanitarian crisis and a dangerous security situation. The capacity for reconstruction and development to be entirely Afghan-led simply does not exist at present.

87. We agree with Clare Short as to the difficulty of the task ahead and the fact that the international development system is at times ill-suited to it. Instead of what is required sustained, pooled, patient institutional capacity building - we have all too often seen donors wanting to flag their projects and tell the world about the effort they are making. The Afghan Transitional Administration's lack of capacity has been a theme which has run throughout the inquiry. Faced with such a lack of capacity, it has fallen to the UN system and NGOs to deliver essential services. We pay full tribute to the work of these organisations: without the efforts of the UN, many would have starved. But there is a tension between the wish to support the Transitional Administration and build its capacity on the one hand, and the urgent need to deliver services and begin the process of reconstruction on the other. Nevertheless, the legitimacy of the Transitional Administration must not be undermined by the creation of "parallel structures". Service delivery by NGOs and the UN, must be seen to be in line with the Afghan priorities set out in the Transitional Administration's National Development Framework.

88. The Afghan Transitional Administration's inability to deliver the services which people expect from their government undermines its credibility. Much has been made of the lack of capacity in Afghanistan but what is really at stake is both the lack of capacity and the lack of institutions. Institution building is not a luxury which can be addressed later; without it the state will be unable to collect revenues and provide essential services as well as security for its citizens.

89. The Afghan Transitional Administration needs to boost its credibility for two reasons. First, elections are only eighteen months away and a huge amount of work is needed to ensure that the newly elected government does not merely take over authority in Kabul, with the rest of the country continuing as a de facto UN mandate. Secondly, realpolitik has made it necessary to incorporate the warlords within the Transitional Administration. This has been is a risky strategy but one that was unavoidable. Tackling the warlords will require institutions, most importantly judicial and human rights institutions, which warlords can be locked into if they wish to continue as part of the government.

90. In a situation where the Aid system is the service provider for most of the country it would be inappropriate to transfer all resources to the Afghan Transitional Administration's National Development Budget. But capacity will not develop by itself. There are ministries within the Transitional Administration which have made progress and at some point donors will have to take a risk and channel funds through those areas in which the government has developed its delivery systems.

305 Afghanistan's reconstruction, regional and country context, William Byrd, October 2002 
91. What is lacking is a sense of a strategy for keeping the momentum moving forward. The Secretary of State sees progress starting with the government linking to the UN and NGO's capacity to deliver and gradually taking on more of the management of that process. This is fine as far as it goes but capacity within the Afghan Transitional Administration has to be built if it is ever to take over the management of anything. And that means pushing more of the funding through it. We have made our own suggestion of how to minimise the risk. If the ARTF is used as the main pool for donor funding and the Transitional Administration, UN and NGOs are each required to bid for allocations, the funding will then flow to whichever organisation has the capacity to deliver.

92. The bulk of assistance has been put into humanitarian relief and of that a large proportion has been in the form of food aid in kind. This has kept alive many Afghans who would otherwise have perished. But in similar vein to the points made above in relation to capacity building, a sense of a strategy - a rolling programme - is now needed, for moving from humanitarian support to reconstruction aid.

93. Our last report cited a lack of security as hampering the humanitarian effort. The same insecurity now threatens to undermine reconstruction. It was an error not to have an ISAF presence in every city, and it is clear that the political will for any expansion of ISAF has now disappeared. We hope that the proposal for Joint Regional Teams will go some way to meet what so many have requested__an expansion of the "ISAF effect".

94. We agree with Clare Short's more general assertion that the provision of security has been under-valued in development thinking. In Afghanistan it is integral to reconstruction. At the same time, reconstruction also underpins security; only a prospering economy can provide alternative livelihoods to soldiering and poppy farming, and the development of security institutions will bring long-term stability.

95. DFID came in for praise from many of our witnesses: it has provided grant aid rather than loans, disbursed funds quickly, channelled resources through the ARTF and continually re-affirmed its long-term commitment to Afghanistan. But the overall response of the international donor community has been insufficient and does not make us optimistic that there is the willingness to stay with Afghanistan for the long term.

96. The problem is one of funding. The UNDP's preliminary needs assessment for Afghanistan came in at almost $\$ 15$ billion over ten years. At Tokyo pledges were taken for five years but in practice the commitments which followed were for a two year period. The funding issue will be revisited in March 2003. But it is already clear that the amounts pledged at Tokyo will be insufficient. A further round of pledging will be necessary with commitments designed to flow at a rate determined by the absorptive capacity of the Afghan Transitional Administration and of the UN system. 


\section{LIST OF MAIN CONCLUSIONS AND RECOMMENDATIONS}

1. We welcome the involvement of regional donors in making pledges to Afghanistan. For too long it has been the same set of countries which put their hands in their pockets when it comes to giving development aid. We urge the UK government to seek to encourage other developed countries to play their full part in the international development system (paragraph 13).

2. There needs to be a rolling programme of pledging, measured against progress on the ground in Afghanistan, to give all donors a chance to demonstrate their continuing commitment and to ensure that they will not leave Afghanistan as a job half completed. There should also be a timetable within which the international community aims to hand over areas of responsibility to the Afghan Transitional Administration (paragraph 17).

3. Sufficient funds must be available for both reconstruction and humanitarian relief and better information about needs will be important in determining how much money is required. We understand the problems involved in separating humanitarian and reconstruction spending but consider that DFID and the international community needs to have a clear strategy, or at least set out milestones, for moving from humanitarian relief towards supporting reconstruction and development. This could involve the prioritisation of humanitarian work which also provides long-term benefits, such as the supply of clean drinking water. (paragraph 21).

4. We believe that the use of loans, as part of a managed economic strategy, will allow the Afghan economy to develop, decreasing its reliance on grant aid and helping to demonstrate that Afghanistan: "is a place where investors can put money with confidence, knowing that they can get a return on their investment and they will be able to repatriate the profits" (paragraph 25).

5. The Afghan Transitional Administration struggles to maintain its credibility because it is under-resourced and not seen by Afghans as delivering those basic public services that people expect from their governments, let alone broader reconstruction. It is essential that the Afghan Transitional Administration establishes it legitimacy; the future stability of the entire country depends on this Administration's ability to govern until an elected government takes over. (paragraph 27).

6. There is a tension between the desire to have Afghan-led development and the need to channel resources where there is the capacity to spend them. (paragraph 33).

7. Capacity and institution building will need to be given a higher priority and quickly if the Afghan Transitional Administration is to govern effectively and plan for the longer term. (paragraph 35).

8. We understand the Secretary of State's concerns about the Afghan Transitional Administration and echo her call for urgent civil service reform. But we also think that putting some money into the parts of the Administration which have reformed would not necessarily be a wasteful exercise. It would help identify where weaknesses lie. At some point soon donors have to take a risk and be willing to allow more funds to be channelled through those areas in which the Afghan Transitional Administration has demonstrated significant progress (paragraph 36). 
9. What is needed are not more coordination meetings but rather a rationalisation of existing procedures (paragraph 38).

10. We welcome the transfer of the Afghan Support Group's responsibilities to the Afghan Transitional Administration as part of the move towards a development forum informed by and involving consultative groups (paragraph 38).

11. We are concerned that UNAMA is not, in practice, co-ordinating the strategies of the UN Agencies and as such is unable to act as an "effective bridge between the international community and the will of the Afghan Transitional Administration". The UN should be given due credit for its work on what is a difficult task but, in line with its mandate which it was given at Bonn, the UN should consider how it can improve the coordination which it is providing. UNAMA should be playing the lead role in countering the perception that the UN is operating as a parallel structure to the Afghan Transitional Administration rather than an assistant to and advocate for Afghan-led reconstruction (paragraph 39).

12. NGOs have been providing services across all sectors in Afghanistan throughout the 23 years of conflict and, in some cases, for even longer. The larger NGOs have provided substantial public services, such as health and education, where there would otherwise be none. They have also acted as implementing partners to the UN within their own mandates, carrying out the work on their behalf to reach the vulnerable. At the moment, in the absence of public service delivery through the Afghan Transitional Administration, NGOs remain the main service providers (paragraph 40).

13. It is right that international aid workers receive international salaries but local employees should also receive fair pay which, at the very least, lifts them out of poverty (paragraph 43 ).

14. Keeping administrative costs and overheads down must be a priority for all donors but especially for those, such as the UN, which are not directly accountable to electorates. It is interesting to note that the Afghanistan Research and Evaluation Unit have interpreted the UN approach of leaving a light institutional footprint as being a "well intentioned and much needed initiative to control agency management costs". One way to address criticisms of high transaction costs would be to ensure full transparency in the spending following disbursement although it is important that any measures to increase transparency are resource neutral in their impact (paragraph 44).

15. We recommend that greater use is made of the Afghanistan Reconstruction Trust Fund (ARTF) with the aim of it becoming the main pool of donor funding from which the Afghan Transitional Administration, UN and NGOs can bid for allocations. Use of the Afghanistan Reconstruction Trust Fund (ARTF) can solve the tension between, on the one hand, a wish to see reconstruction led by Afghans and for the international community to leave a "light footprint" and, on the other, the wish to move resources where there is the capacity to use them (paragraph 46).

16. Persistent insecurity hampers humanitarian relief and is one of the main obstacles to reconstruction. (paragraph 49).

17. Without a specific peacekeeping mandate Joint Regional Teams (JRTs) will be able to do little to bring security to the population and may not enhance the 
aid effort either. We are also concerned about the lack of information about JRTs and recommend that the UK Government issue a statement detailing British involvement and setting out the mandate, range of duties and composition of existing and planned JRTs (paragraph 56).

18. Special emphasis will need to be placed on making the police and military genuinely integrated ethnic forces, not simply an extension of Northern Alliance power (paragraph 59).

19. We see no clear alternative to the approach described by the Secretary of State as saying to the warlords: "Security is now coming outside Kabul, the international community is not going away, American power is not going away, the government will be strengthened, there will be a national army. "Come inside the tent or you are nowhere." (paragraph 60).

20. Given the timescale involved, we believe that the creation of a national army should proceed in step with progress in building the democratic institutions and systems of accountability to the political administration to allow it to function as an army should. (paragraph 60).

21. We are concerned that too great an emphasis may be placed on the creation of a national police force. This strikes us as one area where an incremental and sectoral approach may be more rewarding. A priority for central government is the protection of Afghanistan's porous borders and the securing of customs and other revenues. The establishment of a border protection force might confer considerable benefit in the medium term, as a precursor to the final establishment of a national service. (paragraph 61).

22. We hope that DFID will also play a major part in driving forward a disarmament, demobilisation and reintegration (DDR) programme and that it emphasises the importance of this issue to other donors along with the need to give financial settlements to former fighters (paragraph 63).

23. We are conscious, however, that no disarmament, demobilisation and reintegration (DDR) programme will succeed unless it is underpinned by the employment opportunities that will come with economic development (paragraph 63).

24. Policy towards regional power holders needs to be reviewed continually in the light of what we hope will be the Afghan Transitional Administration's growing legitimacy and eventual control over revenue collection (paragraph 65).

25. We believe the funding of "warlords" by the internationally community to be a short-sighted approach to the fight against terrorism which undermines the long-term objective of achieving stability and security within the country and across the region (paragraph 65).

26. We are concerned about reports of human rights abuses against prisoners and note the comments made by the International Committee of the Red Cross, calling for prisoners to have their legal status determined on an individual basis. There is also, we consider, a lack of equity in the policy under which a line has been drawn under warlords' past crimes, while those acting under their authority have been imprisoned. We recommend an examination of the situation of such prisoners and their release where possible (paragraph 65). 
27. The problem seems not to be a lack of law, but a lack of clarity over which laws are enforceable, and a lack of any mechanism through which to enforce them (paragraph 66).

28. At present there is no clear indication of where suitable people to appoint as judges, lawyers or police officers will be found. Such practical concerns underpin the whole security issue and the successful operation of a fullyfunctioning criminal justice system.

(paragraph 66).

29. We welcome the signing on the 22 December 2002 of a regional noninterference declaration by Afghanistan's closest neighbours, although we are concerned about the absence of Russia, India and Saudi Arabia as key signatories (paragraph 67).

30. We recommend that DFID and other donors, together with the UNDP, carry out an assessment of how opening up regional trade might help the Afghan economy, benefit long-term reconstruction and provide alternative livelihoods for militiamen and poppy farmers (paragraph 67).

31. You cannot ignore the need to build structures and institutions if you are ever to move beyond providing humanitarian relief (paragraph 69).

32. Food for work programmes address the issue of availability of food. But often the food is available, the problem is that people do not have the money to buy it (paragraph 70).

33. Afghanistan is the victim of a chronic rather than an acute food shortage. Food aid in Afghanistan is now the wrong response, as it is in other parts of the world where it has also failed to address food shortages. What is needed is an improvement in food security (paragraph 70).

34. There are still vulnerable communities inside Afghanistan but, by and large, we endorse a move from food to cash for work. We understand the difficulties of such a transition in an fragile economy but the response has to be to build the economy rather than persist in policies which undermine food production. (paragraph 70).

35. The success of the (poppy) eradication programme was soured when, in Kabul, Ashraf Ghani complained that the donor community had failed to honour what he saw as its side of the bargain by providing support for alternative livelihoods as a compensation package. He described it as the single issue which had lost him most credibility within the government and in the regions affected. (paragraph $\mathbf{7 1}$ ).

36. The gradual build-up of a law enforcement and judicial system will, we hope, marginalise the illegal activity of poppy production. There will then be a chance to offer farmers something which, while not as lucrative as poppy growing, will nevertheless have tangible benefits. The Secretary of State told us that although poppy farmers could not realistically be tempted away from poppy cultivation with the promise of equally valuable crops, they could and should be offered the alternative of "a better life that is a legitimate life" which would also allow them to reap the benefits of stability and provision of public services such as education for their children. We commend this approach. Of course, none of this deflects from the UK's responsibility to address its own demand for the drug. As Clare Short pointed out, "if we get Afghanistan to 
the point where there is no drug production, it will come to the UK from somewhere else." (paragraph 75).

37. DFID has a good track record in its commitment to gender issues and could act as an advocate for a thorough gender main-streaming approach within all donor activities and in political dialogue with the government. DFID should ensure that funding is provided for a gender audit (paragraph 78).

38. We believe that education to secondary level, for both boys and girls, must be a priority and, in the long-term, will be the best method of addressing gender issues. (paragraph 79).

39. What is essential is that the Afghan Transitional Administration has a sustainable refugee return programme. Neighbouring states will have to be helped as well if forced or unsustainable repatriation is to be avoided (paragraph 81).

40. The task now is to create a constitution, build institutions and a structure of accountability within which these regional power holders have to operate. We hope that the Human Rights Commission will be a vehicle for this. (paragraph 82). 